\title{
Croatia: Submerged Prehistoric Sites in a Karstic Landscape
}

\author{
Irena Radić Rossi, Ivor Karavanić, \\ and Valerija Butorac
}

\begin{abstract}
Croatia has a long history of underwater archaeological research, especially of shipwrecks and the history of sea travel and trade in Classical Antiquity, but also including intermittent discoveries of submerged prehistoric archaeology. Most of the prehistoric finds have been discovered by chance because of construction work and development at the shore edge or during underwater investigations of shipwrecks. Eustatic sea-level changes would have exposed very extensive areas of now-submerged landscape, especially in the northern Adriatic, of great importance in the Palaeolithic and early Mesolithic periods. Because of sinking coastlines in more recent millennia, submerged palaeoshorelines and archaeological remains of settlement activity
\end{abstract}

I. R. Rossi $(\bowtie)$

Department of Archaeology, University of Zadar,

Zadar, Croatia

e-mail: irradic@unizd.hr

I. Karavanić

Faculty of Humanities and Social Sciences,

Department of Archaeology, University of Zagreb,

Zagreb, Croatia

Department of Anthropology, University of

Wyoming, Laramie, WY, USA

e-mail: ikaravan@ffzg.hr

V. Butorac

Faculty of Sciences, Department of Geography,

University of Zagreb, Zagreb, Croatia

e-mail: vbutorac@geog.pmf.hr extend as late as the medieval period. In consequence, the chronological range of prehistoric underwater finds extends from the Mousterian period through to the Late Iron Age. Known sites currently number 33 in the SPLASHCOS Viewer with the greatest number belonging to the Neolithic or Bronze Age periods, but ongoing underwater surveys continue to add new sites to the list. Systematic research has intensified in the past decade and demonstrates the presence of in situ culture layers, excellent conditions of preservation including wooden remains in many cases, and the presence of artificial structures of stone and wood possibly built as protection against sea-level rise or as fish traps. Existing discoveries demonstrate the scope for new research and new discoveries and the integration of archaeological investigations with palaeoenvironmental and palaeoclimatic analyses of submerged sediments in lakes and on the seabed. A major challenge for the future is to develop better procedures for the integration of scientific research, commercial and industrial development, and the management and protection of the underwater heritage.

\section{Keywords}

Mousterian · Palaeolithic · Mesolithic .

Neolithic $\cdot$ Bronze Age $\cdot$ Submerged landscapes · Underwater settlements · Wood 


\subsection{Introduction}

Underwater archaeological research in Croatia, as in many other Mediterranean countries, focused for decades mainly on Classical Antiquity, thanks to abundant evidence relating to Greek and Roman seafaring (Vrsalović 2011). Submerged prehistoric sites were rarely reported in archaeological bibliographies (e.g., Brusić 1977; Mihovilić 1992, 1995a, b), and it is only during the past decade that increased attention has been paid to this theme, notably an overview of selected finds by Benjamin et al. (2011).

Nevertheless, isolated occurrences have been reported since the nineteenth century, such as the remains of a prehistoric fortified settlement on the island of Korčula in Southern Dalmatia (Vuletić Vukasović and Radić 1887) and a Neolithic axe recovered from the estuary of the Cetina River in Central Dalmatia (Bulić 1898). In the 1960s, temporary drying out of the Nin saltpans for repairs revealed remains of a submerged Early Neolithic settlement with a rich cultural layer at Čvrljevića Ograda (Batović 1965), while partially or fully submerged Late Iron Age burials with contracted skeletons in chambers made of stone slabs were discovered at the entrance to the Nin lagoon at Kraljicina plaža and in the shallow coastal zone of the Ždrijac Peninsula (Brusić 1969, 2002; Glogović 1989). A well-preserved example with stone slabs $1 \mathrm{~m}$ high and 'lying at the depth of over $1 \mathrm{~m}$ ' contained skeletal remains and a bronze needle with a spirally twisted head dated to the eighth century BC Glogović 1989, p. 9).

In the 1970s, a trial survey in South Liburnia (Zadar and Šibenik area) revealed at least four submerged coastal sites with Palaeolithic, Bronze Age, and Iron Age material (Brusić 1977). All the sites-Ričul west of Turanj, Oštarije near Biograd, Sv. Justina in front of Pakoštane, and Stipanac in Lake Prokljan - are on small islands and are partly submerged, with evidence of structures (whether natural or artificial is not clear) that once connected them to the mainland (see Fig. 18.1). This evidence pointed to the likelihood that systematic surveys on both sides of the Pašman Channel would lead to new discoveries both on land (Batović 1988, 1990a) and underwater (Radić Rossi 2011).

During the past decade, several factors have promoted new interest in the detection and interpretation of submerged prehistoric sites. These include more detailed investigation of sea-level change and submerged karstic features (Benac et al. 2004, 2008; Surić et al. 2004, 2005, 2010; Surić 2009; Surić and Juračić 2010; Faivre et al. 2010; Furlani et al. 2011; Marriner et al. 2014; Radić Rossi and Cukrov 2017; Lončar et al. 2017, 2018; Faivre and Butorac 2018; Radić Rossi et al. 2018), leading to increased awareness of the prehistoric archaeological potential of the Croatian seabed (Benjamin and Črešnar 2009; Benjamin et al. 2011) and of the threats to the coastal and underwater heritage posed by construction works and environmental change (Radić Rossi 2008).

Typically, in the past, underwater sites have been located through deepening and reconstruction of harbours and saltpans (Batović 1965; Mihovilić 1992; Radić Rossi 2008), recreational diving (Brusić 2004; Radić Rossi 2009), and pedestrian survey of beaches and intertidal zones (Mihovilić 1995a, b). More recently, new methods have been introduced including the use of satellite imagery to assess larger areas, systematic survey by SCUBA (Koncani Uhač 2009; Bekić et al. 2011; Pešić 2013; Brusić and Parica 2014) or new technologies (Radić Rossi and Boetto 2013; Soura et al. 2013), and the more systematic incorporation of geological, geomorphological, and palaeolandscape research (Marriner et al. 2014; Miko et al. 2016; Ilijanić et al. 2018; Radić Rossi et al. 2018). Excavations have begun in some promising shallow-water areas (Koncani Uhač and Čuka 2016; Čelhar et al. 2017).

This chapter summarises the current state of research, drawing on published sources and the personal experience of the authors. We outline the evidence for changes in palaeogeography and sea level and describe selected evidence from sites that best illustrate the chronological range and the variety and preservation of underwater material, proceeding in chronological order from earliest to latest. 


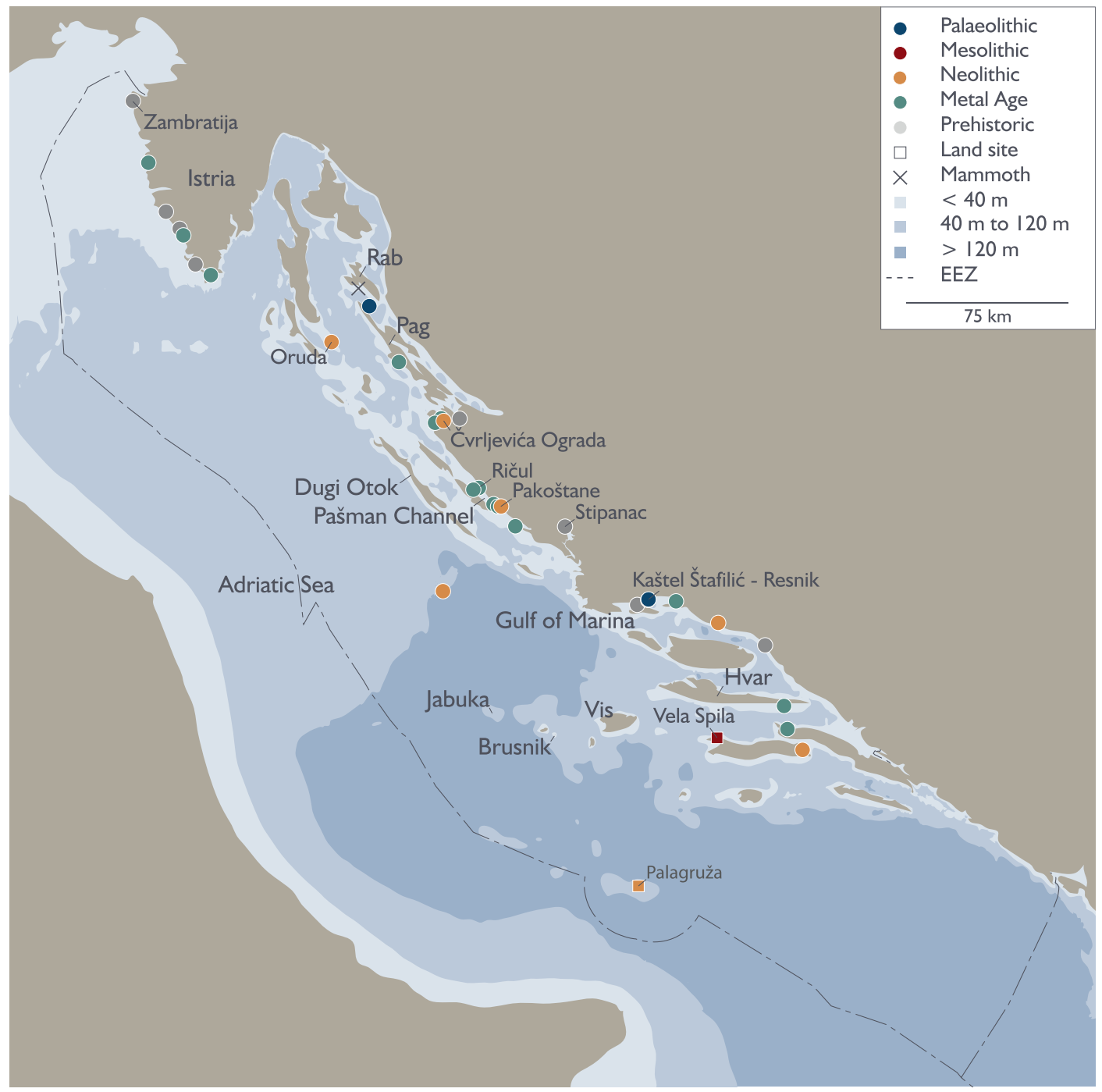

Fig. 18.1 Distribution of underwater sites showing names of key sites and other places mentioned in the text and the boundary of the Exclusive Economic Zone. Site information from the SPLASHCOS Viewer http://splashcos-viewer.eu. Drawing by Moritz Mennenga

\subsection{Palaeogeography and Sea- Level Change}

The Adriatic Sea is the northernmost basin of the Mediterranean, and the east Adriatic coast, including part of northern Italy, Slovenia, Croatia, Bosnia-Herzegovina, Montenegro, and Albania, is dominated by the maritime sector of the Dinaric Alps. This mountain range originated 240 million years ago (Ma) with shallow-water sedimentation on the Adria microplate, which continued throughout the Mesozoic era (240$65 \mathrm{Ma}$ ), resulting in an 8-km-thick succession of dolomites and limestones-the Adriatic Carbonate Platform. Uplift of this platform began towards the end of the Mesozoic with subduction of the Adria microplate beneath the Eurasian Plate and uplift of the Dinaric Alps with major faulting oriented on a NW-SE axis. The main episodes of mountain building continued into the Miocene period (c. 23-5 Ma) accompanied by 
exceptional faulting, folding, and thrust structures and the initiation of karst processes (dissolution of limestone and the formation of underground channels and caves) (Vlahović et al. 2002, 2005; Mocochain et al. 2009; Pikelj and Juračić 2013).

The resulting landscape is one of mountain ridges oriented on a NW-SE axis with intermontane valleys in parallel, and this topography continues offshore to form an extensive submerged landscape that was exposed during periods of lower sea level, just leaving the hill tops above modern sea level as an archipelago of some 1200 islands and islets (Fig. 18.1).

This pattern of offshore anticlines (ridges), represented by the present-day islands, and synclines (valleys), represented by present-day bays and channels, aligned in parallel with the coast and the main strike orientation of the Dinarides, is especially well developed along the Dalmatian coast, which has given its name to this type of coast in the world literature (Fairbridge 1968; Kelletat 2005; Pikelj and Juračić 2013).

Because of its karst geology, Croatia has one of the most heavily indented coastlines in the Mediterranean. The total length of the coastline is $6176 \mathrm{~km}$, of which the islands account for $4398 \mathrm{~km}(71 \%)$ and an area of c. $3259 \mathrm{~km}^{2}-$ $5.8 \%$ of the total Croatian land area (Croatian Ministry of the Sea, Transport and Infrastructure; Duplančić Leder et al. 2004). The coastline is predominantly an erosional rocky one with scattered pocket beaches and accumulation of sediment only near river mouths (Bognar et al. 2012). In the north of the Adriatic, the rivers flow through flysch geology susceptible to erosion and have carried large quantities of sediment into the sea. Along the Croatian coast, the rivers carry relatively little sediment, and fresh water also flows underground and emerges as submarine springs, which are abundant along the coast.

The largest palaeokarst depressions lying between present-day islands at depths of $-40 \mathrm{~m}$ to $-90 \mathrm{~m}$ contain sedimentological and geomorphological archives of climate and relative sealevel changes and would have favoured the development of shallow freshwater lakes when sea level was low during the Last Glacial period (Miko et al. 2016; Karavanić and Barbir 2017).

The maximum sea-level regression in the northern Adriatic at the Last Glacial Maximum (LGM) was c. $-112 \mathrm{~m}$, exposing a very extensive area of coastal lowland (Fig. 18.1), and sea level rose after 18,000 years ago to reach the modern level after c. 6000 years ago (Šegota 1983; Benac and Juračić 1998). Although the eustatic component is the dominant contribution to relative sealevel rise, the position of palaeoshorelines has been affected by both tectonic and glacio-isostatic movements as indicated by a variety of studies of geomorphological, archaeological, and historical markers of relative sea level during the past two decades (Benac et al. 2004, 2008; Lambeck and Purcell 2005; Antonioli et al. 2007; Surić 2009; Faivre et al. 2010, 2011, 2013; Lambeck et al. 2010, 2011; Florido et al. 2011; Furlani et al. 2011, Marriner et al. 2014; Benjamin et al. 2017; Faivre and Butorac 2018; see also Bailey et al., Chap. 1, this volume). The tectonic signal is recognised as the most variable and uncertain component contributing to relative sea-level change on the Croatian coastline (Faivre and Butorac 2018), and the impact of neotectonic activity varies in different areas. In the south, in the Dubrovnik area, the coastline shows no vertical movement, whereas the coastlines in the north are subsiding.

The topography of the now-submerged landscape, with its extensive and well-watered valleys partially enclosed by hill barriers, would have created an attractive environment for huntergatherer populations and large mammals during the Last Glacial. As sea level rose, these valleys would have been transformed into brackish lagoons and marshes and ultimately marine basins, with considerable potential for the exploitation of aquatic resources. Moreover, as this landscape became slowly inundated by sea-level rise, archaeological deposits in this hill-valley system would have been relatively well protected by hill ridges and islands from the destructive impact of waves, which can reach a maximum height of $10 \mathrm{~m}$ during storms at the present day. This factor, together with relatively low rates of marine sedimentation sufficient to provide a pro- 

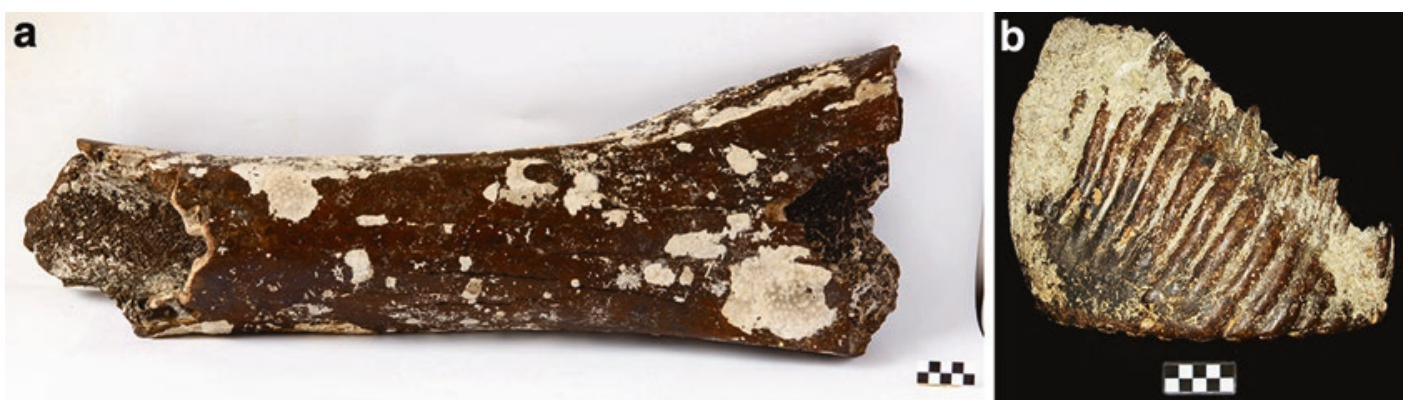

Fig. 18.2 Remains of Mammuthus meridionalis adriacus n. ssp. (a) Diaphysis of left femur, anterior view. (b) Upper third molar, buccal view. The finds were dredged from a depth of $80 \mathrm{~m}$ on the seabed between the islands of Rab and Laganj. Palaeonotlogical analysis indicates an early Middle Pleistocene age. Scale in $\mathrm{cm}$. Photos courtesy of the Archives of the Institute for Quaternary Paleontology and Geology, Croatian Academy of Sciences and Arts

tective cover but not so thick as to deeply bury archaeological deposits beyond easy reach, suggests good prospects for the preservation and discovery of underwater archaeological sites. In 1979, a fishing trawler dredged a mammoth molar tooth and femur (Mammuthus meridionalis adriacus $\mathrm{n}$. $\mathrm{spp}$ ) from a shallow depression on the seabed with a fill of quaternary terrestrial sediments, c. $8 \mathrm{~km}$ south-west of the island of Pag at a depth of $-80 \mathrm{~m}$ (Fig. 18.2; Malez and LenardićFabić 1988; Mauch Lenardić 2012). Dated on palaeontological grounds to the early Middle Pleistocene $(\leq 750 \mathrm{ka})$, this find is testament to the preservation potential of the Adriatic seabed.

\subsection{Archaeological Context}

The archaeological sequence in Croatia extends back to the Lower Palaeolithic period, represented by the site of Šandalja I (Malez 1979; Table 18.1). Open-air finds on the island of Dugi Otok have also been attributed to the Lower Palaeolithic (Batović 1988), but from their similarities with well-provenanced material elsewhere, it is more likely that these belong to the Middle Palaeolithic (Karavanić 2000, 2004; Krile and Vujević 2017). Middle Palaeolithic sites are more common and are best known from the cave sites of Krapina and Vindija in the north-west, famous for their Neanderthal fossils. In recent decades, new cave and open-air sites have been found in the hinterland of the northern Dalmatian coast and open-air sites on some of the neighbouring islands (Vujević 2009; see also Perhoč 2009). Systematic excavations at the cave sites of Mujina pećina and Velika pećina in Kličevica have produced stratified lithic and faunal assemblages dated at $45-39 \mathrm{ka}$ cal. BP, a period that spans the late Neanderthals and the earliest known anatomically modern humans (AMH) in Europe (Karavanić et al. 2008). Open-air sites occur near sources of chert in the hinterland and on the neighbouring islands. They indicate visits to the islands, most likely when connected to the mainland at low sea level and suggest the exploitation of the now-submerged landscape.

Early Upper Palaeolithic sites are rare in the eastern Adriatic (Karavanić 2009; Mihailović 2009), and there appears to be a chronological gap between them and the preceding Middle Palaeolithic. The reasons for this are unclear but may reflect concentrations of settlement on the now-submerged landscape at a time when it was expanding to its maximum extent at the LGM and loss of sites inundated by subsequent sealevel rise, a genuine temporal hiatus between the last Neanderthals and the first anatomically modern humans-perhaps related to the devastation caused by the Campanian Ignimbrite volcanic eruption, low population densities in the region, or simply a lack of research (Karavanić 2009; Papagianni 2009; Papagianni and Morse 2013; Mihailović and Whallon 2017).

Late Upper Palaeolithic (Epigravettian) sites appear in larger numbers after the LGM and are 
Table 18.1 Chronological chart showing principal periods and cultures for Croatia

\begin{tabular}{|c|c|c|c|}
\hline cal BC & \multirow[t]{2}{*}{ Period } & \multicolumn{2}{|c|}{ Culture or Important Sites } \\
\hline & & Istria & Dalmatia \\
\hline $400-0$ & Late Iron Age & $\begin{array}{c}\text { Histrian Culture } \\
\text { Phase VI }\end{array}$ & $\begin{array}{c}\text { Liburnian Culture: } \\
\text { Phases V-VI } \\
\text { Delmatian Culture: } \\
\text { Phases IV-V } \\
\text { Greek Culture }\end{array}$ \\
\hline $1,100-400$ & Early Iron Age & $\begin{array}{l}\text { Histrian Culture: } \\
\text { Phases I-V }\end{array}$ & $\begin{array}{l}\text { Liburnian Culture: } \\
\text { Phases I-IV } \\
\text { Delmatian Culture: } \\
\text { Phases I-III }\end{array}$ \\
\hline $1,300-1,100$ & Late Bronze Age & \multicolumn{2}{|c|}{ Urnfield Culture } \\
\hline $1,900-1,300$ & Middle Bronze Age & Castellieri Culture & Dinara 2 \\
\hline $2,300-1,900$ & Early Bronze Age & \multirow[b]{2}{*}{ Ljubljana-Adriatic } & Cetina/Dinara 1 \\
\hline $3,000-2,300$ & Late Eneolithic & & Ljubljana-Adriatic \\
\hline \multirow{2}{*}{$4,000-3,000$} & Middle Eneolithic & \multirow{2}{*}{ Brijuni Culture } & \multirow{2}{*}{ Nakovana Culture } \\
\hline & Early Eneolithic & & \\
\hline $4,800-4,000$ & Late Neolithic & Hvar Culture & \\
\hline \multirow[t]{2}{*}{$5,500-4,800$} & \multirow[t]{2}{*}{ Middle Neolithic } & \multirow[t]{2}{*}{ Danilo Culture } & Danilo Culture \\
\hline & & & \multirow{2}{*}{$\begin{array}{l}\text { Vela Luka Culture } \\
\text { Impresso Culture }\end{array}$} \\
\hline $6,000-5,500$ & Early Neolithic & Impresso Culture & \\
\hline $10,000-6,000$ & Mesolithic & $\begin{array}{l}\text { Pupićina peć } \\
\text { Šandalja II }\end{array}$ & $\begin{array}{c}\text { Vela Spila, Kopačina } \\
\text { Vlakno }\end{array}$ \\
\hline $30,000-10,000$ & $\begin{array}{c}\text { Upper Palaeolithic } \\
\text { (Epigravettian, Gravettian } \\
\text { Aurignacian) }\end{array}$ & Šandalja II & Vlakno \\
\hline $200,000-30,000$ & $\begin{array}{l}\text { Middle Palaeolithic } \\
\text { (Mousterian) }\end{array}$ & & Mujina pećina \\
\hline$>200,000$ & Lower Palaeolithic & Šandalja I & \\
\hline
\end{tabular}

present on the Adriatic coast and its hinterland and offshore islands, with evidence for movement of raw materials between northern Italy, Istria, and inland Croatia (Malez 1979; Cancellieri 2011; Vukosavljević et al. 2011, 2015; Karavanić et al. 2013, 2015). It is likely that there was extensive activity on a landscape that is now submerged at depths of 60-110 m below present sea level and that many sites present there have been submerged by subsequent sea-level rise (Šegota 1982; Miracle 1995; Whallon 2007). Vlakno Cave on the Island of Dugi Otok has deposits dated to 14.6-14.1 ka cal BP and would have looked out onto this submerged landscape. The presence in the archaeological deposits of marine shells of Cyclope rustica, Columbella rustica, 
Glycymeris, and Dentalium, collected for decorative purposes, is evidence of visits to a coastline that would have been more distant than today (Benjamin and Črešnar 2009; Vujević and Parica 2009; Vukosavljević and Karavanić 2015).

The Mesolithic is well represented by numerous sites in the Adriatic region, especially in Istria but also in Dalmatia (Komšo 2008). Marine shells found at many inland Mesolithic sites in northern Italy (e.g., Bus de la Vecia, Pradestel, Riparo Gaban, Romagnano, Vatre di Bambana) indicate contact with an Adriatic coastline that would still have been lower than present (Álvarez Fernández 2003; Komšo 2008; Komšo and Vukosavljević 2011), and by implication the use of the now-submerged landscape and its palaeoshorelines. At the cave site of Vela Spila on Korčula Island, which would have been a peninsula during the Mesolithic period, the Mesolithic layers, dated at c. 9 ka cal BP, contain artefacts made from gabbrodiorite rock sourced to the islands of Vis, Jabuka, and Brusnik, providing evidence of navigation in the open sea over distances of at least $20 \mathrm{~km}$ (Radić 2011). Large quantities of fish bones were found in the Mesolithic layers, principally of mackerel (Scombridae) and eel (Congridae and Muraenidae), also dolphin bones (Radić 2011; Rainsford et al. 2014), providing additional evidence for the importance of marine resources.

The transition from Mesolithic to Neolithic at c. 8 ka cal BP involved mainly immigrants from further east bringing new crops and domestic animals. The extent to which the pre-existing huntergatherer population was involved in these new developments remains unclear since there is a chronological gap of at least several hundred years between the Mesolithic and the Early Neolithic (Forenbaher and Kaiser 2005; Forenbaher and Miracle 2006; Forenbaher et al. 2013; Moore 2014). What is clear from the distribution of Early Neolithic impresso ware is that the pattern of dispersal followed the coastline and that the immigrants and their crops and animals must have travelled by sea, involving significant seafaring abilities including crossings of the Adriatic between Italy and Croatia. This is especially clear from the presence of Early Neolithic pottery and tools made on Italian (Apulian) chert on the island of Palagruža, midway between the coastlines of Italy and Croatia, which must have involved sea crossings of at least $48 \mathrm{~km}$ (Korbar et al. 2009; Forenbaher and Kaiser 2005; Forenbaher 2011, 2018a).

Alongside the establishment of farming in areas with suitable soils, this maritime emphasis persisted and intensified in the Middle and Late Neolithic (Danilo and Hvar cultures), respectively (Table 18.1; Težak Gregl 1998), with the use of caves as well as open-air sites in the Danilo culture, the importation of Middle Neolithic ware from southern Italy, and the circulation of obsidian sourced from the islands of Lipari in the Tyrrhenian Sea and Melos in the Aegean (Radić 2011), with obsidian from both sources present on the Palagruža Archipelago (Tykot in Forenbaher 2018a; see also Castagnino Berlinghieri et al., Chap. 16 and Galanidou et al., Chap. 19, this volume).

Given this maritime emphasis, and the fact that palaeoshorelines of this period are now submerged at depths as much as $10 \mathrm{~m}$ below present, it must follow that important archaeological evidence, and especially remains of settlements on the shore associated with sea travel, must be sought on the seabed. Similar comments apply to the subsequent periods of the prehistoric sequence, the Late Eneolithic and the Bronze Age, when relative sea level continued to rise, submerging palaeoshorelines of this period at depths of 2-3 $\mathrm{m}$. This was a period that, along with the immigration of new people and developments in social organisation, witnessed an intensification of maritime activities in trade and the use of offshore islands (Majnarić Pandžić 1998; Forenbaher 2018a, b).

Throughout the archaeological sequence described above, submerged landscapes and palaeoshorelines would clearly have been significant in a variety of roles, as areas of fertile territory for hunting and gathering, especially during periods of extreme low sea level in the northern Adriatic, as locations for the exploitation of marine resources, as pathways of communication and colonisation, as submerged territory that may have harboured settlements now lost 
that would otherwise explain gaps in the archaeological sequence on land, and in the later periods as bases for sea travel and trade. The evidence for these activities must now lie, for the most part, below present sea level.

\subsection{Underwater Sites}

There are 33 underwater sites currently registered in the SPLASHCOS Viewer (Table 18.2, Fig. 18.1). They range in age and site type from unstratified Middle Palaeolithic stone tools to Iron Age burials. The majority, 17 sites (52\%), represent in situ cultural layers, with collections of unstratified material in second place at 11 sites $(33 \%)$. All sites in these two categories lie in a depth range of 1.5-5.5 m below present sea level, and the majority are Neolithic or Bronze Age in date. One of these, shown as prehistoric in Table 18.1, has both Palaeolithic stone tools and Bronze Age material and is also anomalous in the sense that it is located offshore of the small island of Stipanac in Lake Prokljan, which is a brackish water lake $12 \mathrm{~km}$ inland from the coast but connected to the sea via the Krka River.

\subsubsection{Palaeolithic}

\subsubsection{Kaštel Štafilić-Resnik}

This site is in the Gulf of Kaštela and was found by a local diver c. $300 \mathrm{~m}$ offshore at a depth of $4 \mathrm{~m}$ and in the immediate vicinity of a wellknown Hellenistic and Roman settlement on one side and a presumed site from the Neolithic period on the other (Brusić 2004; Radić Rossi
2009; Kamenjarin and Šuta 2011). Research-led investigation, including underwater excavation, recovered additional artefacts, in total about 100 pieces, of which half are tools. These are of Middle Palaeolithic type including typical Mousterian centripetal cores and side scrapers, with the addition of some possible Upper Palaeolithic tools (Fig. 18.3; Karavanić et al. 2009, 2015; Karavanić 2015; Janković et al. 2011; Barbir 2015). Most of the artefacts are on the seabed surface and have been disturbed by marine currents but probably not moved very far from their original position. The material is similar to the finds from the Mousterian cave site of Mujina pećina, which is c. $8 \mathrm{~km}$ inland from Kaštel Štafilić-Resnik. Mujina pećina was used as a seasonal site in autumn and spring, and the two sites could have been used by the same people at different seasons (Miracle 2005; Karavanić et al. 2008; Karavanić et al. 2014a, b). About $150 \mathrm{~m}$ west of the Mousterian site, at Stara plaža, Early Neolithic potsherd and numerous wooden stakes have been found in water depths of 0.5-3 $\mathrm{m}$, but a single radiocarbon date on the wood indicating a date in the Classical period puts a question mark over the status of this material and indicates the need for further investigation.

Other Palaeolithic finds are a single Mousterian tool offshore of Povljana on the island of Pag (Batović 1990b; Vujević et al. 2017) and stone tools of possible Mousterian type at a depth of $3 \mathrm{~m}$ at Stipanac in Lake Prokljan (Brusić 1977; Malez 1979; Vujević et al. 2017; Karavanić and Barbir 2017) close to a small island which is a rich source of chert raw material (D. Vujević and M. Parica, personal communication 2018).

Table 18.2 Distribution of Croatian underwater finds by site type and broad chronological period

\begin{tabular}{|c|c|c|c|c|c|c|c|c|c|}
\hline \multirow[b]{2}{*}{ Site type } & \multirow[t]{2}{*}{ Pal } & \multirow[t]{2}{*}{$\mathrm{Neo}$} & \multirow[t]{2}{*}{ Neo-Bronze } & \multirow[t]{2}{*}{ Bronze } & \multirow[t]{2}{*}{ Bronze-Iron } & \multirow[t]{2}{*}{ Iron } & \multirow[t]{2}{*}{ Prehist } & \multicolumn{2}{|c|}{ Total } \\
\hline & & & & & & & & $\mathrm{N}$ & $\%$ \\
\hline Culture layer in situ & - & 5 & 4 & 7 & - & 1 & - & 17 & 52 \\
\hline Unstratified collection & 2 & 1 & 3 & 2 & 1 & 1 & 1 & 11 & 33 \\
\hline Single find & 1 & 1 & - & 1 & - & - & - & 3 & 9 \\
\hline Burial & - & - & - & - & - & 2 & - & 2 & 6 \\
\hline Total N & 3 & 7 & 7 & 10 & 1 & 4 & 1 & 33 & 100 \\
\hline$\%$ & 9 & 21 & 21 & 30 & 3 & 12 & 3 & & 99 \\
\hline
\end{tabular}

Data from the SPLASHCOS Viewer at http://splashcos-viewer.eu 
Fig. 18.3 Middle

Palaeolithic

(Mousterian) lithic artefacts from Kaštel Štafilić-Resnik collected from the seabed at a depth of 3-4.5 m. Left:

Core. Right: Flakes with natural edge damage. Scale in $\mathrm{cm}$. Photo by Ivor Karavanić

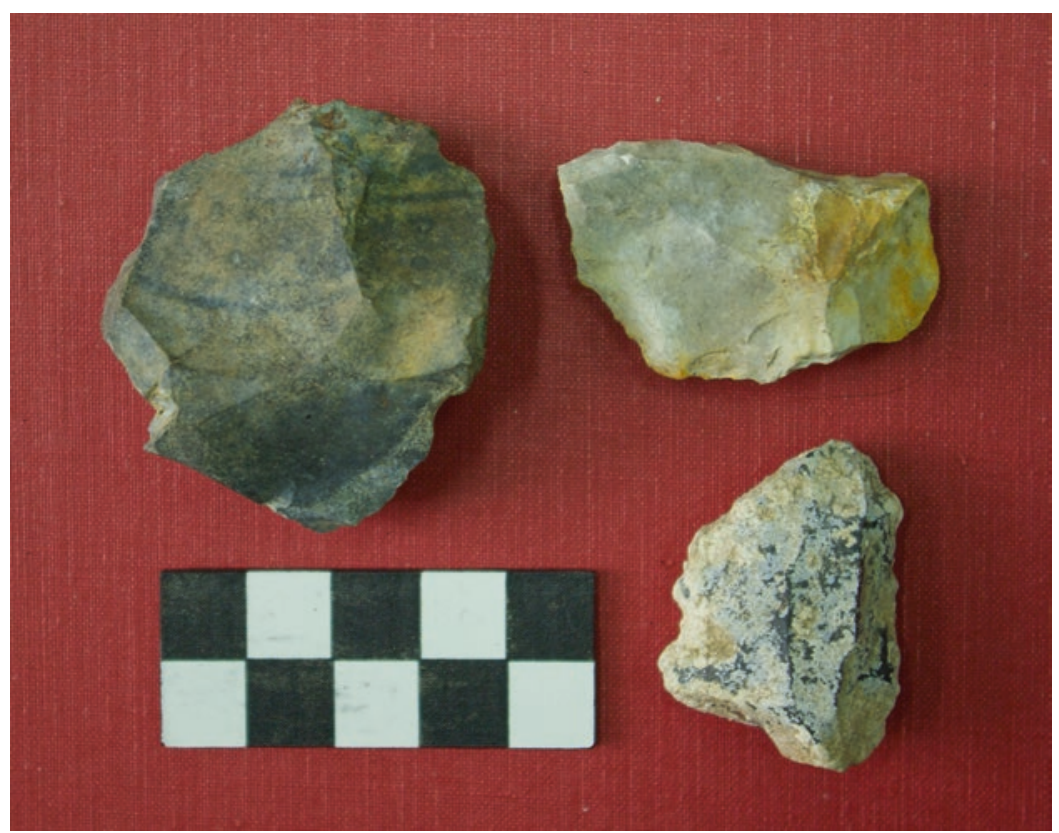

\subsubsection{Neolithic and Eneolithic}

Underwater finds of Neolithic or Eneolithic age are relatively abundant, and many refer to remains of settlements judging by the presence of pottery, animal bones, and wooden artefacts that may refer to dwelling structures or other wooden structures of unknown purpose.

\subsubsection{Pakoštane}

This site lies c. $100 \mathrm{~m}$ offshore between the modern coast (Janice) and the small island of St. Justina (Fig. 18.4) and was discovered during the investigation of a Roman shipwreck (Radić Rossi and Antonioli 2008; Bekić et al. 2011, 2016; Pešić 2012; Radić Rossi et al. 2018; Vujević and Meštrov 2018). The prehistoric finds are at a depth of 4-4.5 m below present sea level. Stone artefacts were scattered over an area of $2500 \mathrm{~m}^{2}$. A test excavation was carried out in a $2 \times 4 \mathrm{~m}$ trench, revealing cultural finds in a 1-m-thick layer closely associated with the remains of a wooden structure. The total assemblage including surface and excavated finds comprises over 2000 potsherds of coarse pottery, stone artefacts, animal bones, and worked wood (Fig.18.5). The stone artefacts total 156 pieces of which 42 are worked tools, mostly edge-retouched blades and bladelets. The wood is radiocarbon-dated at $6.6 \mathrm{ka}$ cal BP indicating a Late Neolithic date for the assemblage. On the seaward side of the site is an extensive stone structure which represents a natural beachrock formation indicating a palaeoshoreline dated at 5.4-5.2 ka cal BP (Eneolithic). The number and variety of artefacts and the occurrence of technical pieces demonstrating in situ manufacture of the flint tools all indicate the presence of a settlement, and the geological context demonstrates that it was located on dry land at the time of occupation.

\subsubsection{2 Čvrljevića Ograda}

This site was discovered in the inner Nin lagoon during maintenance of the Nin saltpans in 1955, and further investigation found cultural materials over an area of $40 \mathrm{~m} \times 100 \mathrm{~m}$. Rescue excavations identified a 20- to 50-cm-thick cultural layer with potsherds of Early Neolithic impresso ware (Fig. 18.6), grindstones made of sandstone, 36 chert tools, marine shells, and bones of domes- 


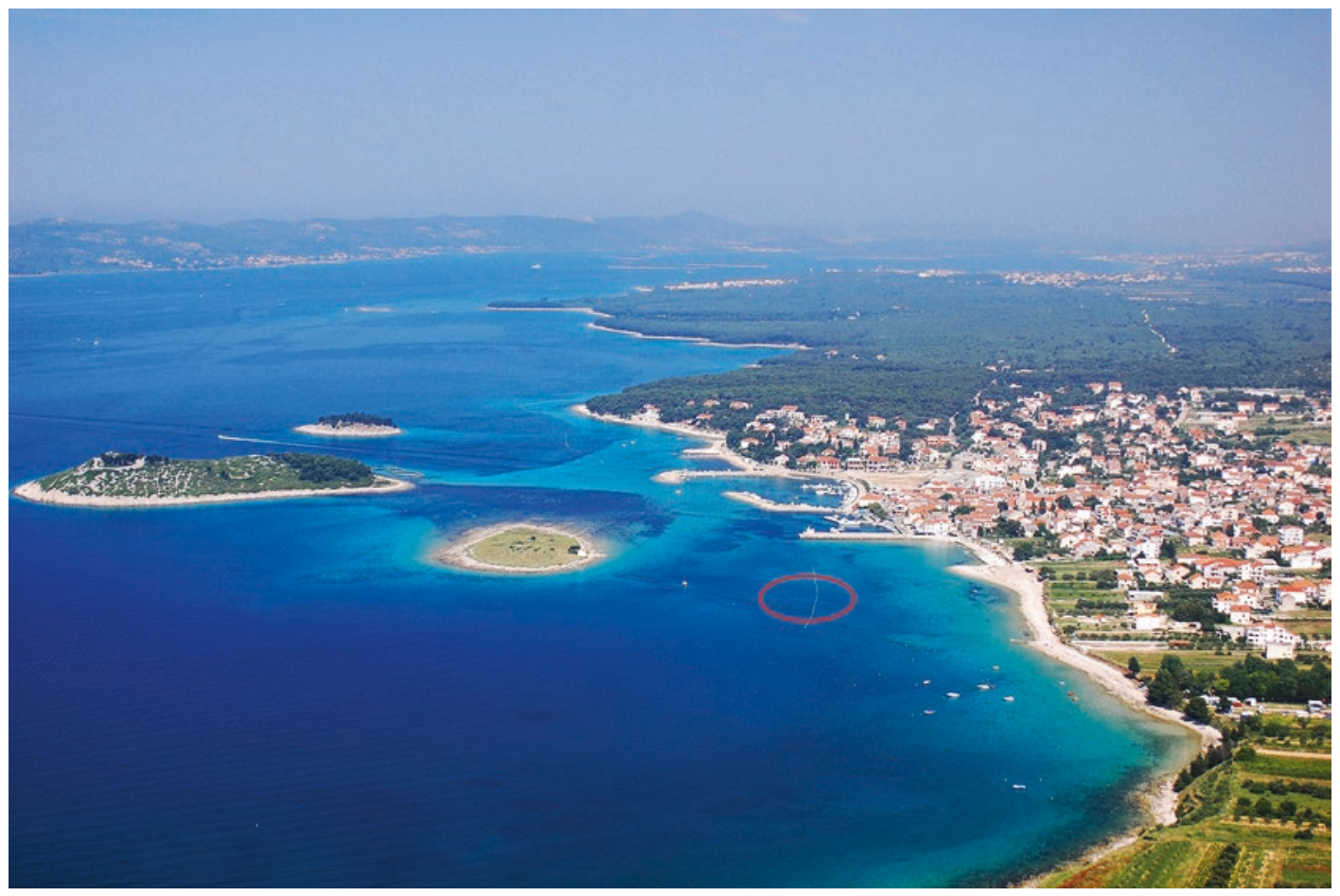

Fig. 18.4 Aerial view of Pakoštane showing the location of the archaeological site (circled in red) and the Pašman Channel in the background. Photo courtesy of Tourist Board Pakoštane

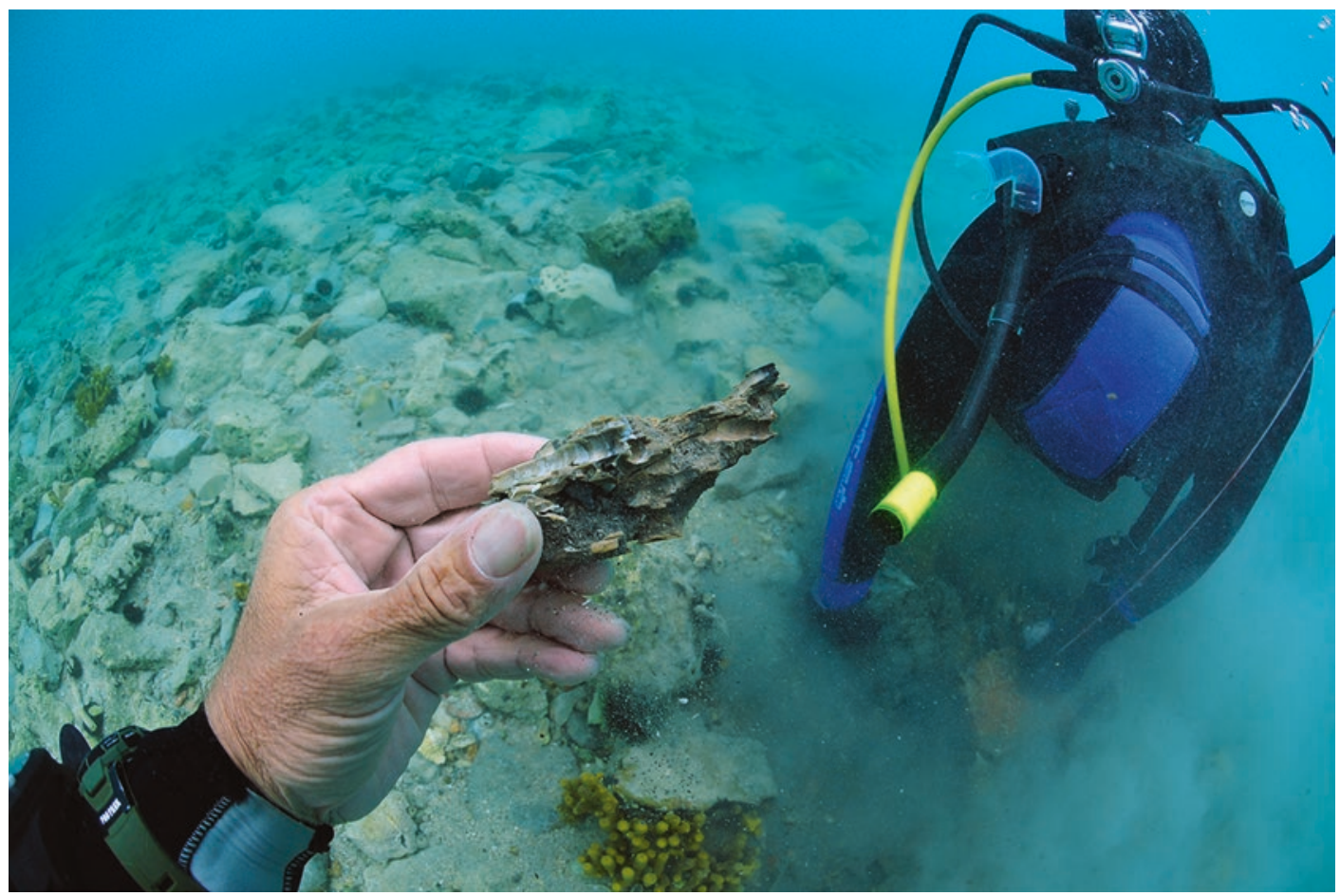

Fig. 18.5 Diver at Pakoštane holding a piece of wood from the top layer of the site. Photo by Fabrizio Antonioli 
tic animals (cattle, sheep, and goat) (Batović 1965). The site appears to have been located on the edge of a marine lagoon that subsequently dried out. At the time of occupation, it was several metres above sea level according to Batović (1965) but was later inundated by sea-level rise and is now below present sea level. Relatively little is known in detail about this site, but it is important as one of the few submerged sites of Early Neolithic date and a site that first helped to identify the presence of an Early Neolithic in Croatia and evidence that shorelines of this period had been submerged by subsequent sealevel rise. Two other sites, the Školjić Rock in front of Neviđane on the island of Pašman and Donje Blato-Mlini on the island of Korčula (Vuletić Vukasović and Radić 1887), have recently been attributed to the Neolithic period (Mate Parica personal communication 2018) and await more detailed investigation.

\subsubsection{Zambratija}

Well-preserved remains of a settlement dated to the Early Eneolithic at c. 6 ka cal BP were discovered in the bay of Zambratija in 2008 during the investigation of a sewn plank boat of Late Bronze Age/Iron Age date (c. 3 ka cal BP) and other remains of Roman and Late Medieval data (Koncani Uhač 2009; Benjamin et al. 2011; Koncani Uhač and Čuka 2016; Koncani Uhač et al. 2017).

The site lies in the north-western part of the bay, at a depth of 2.4-3.1 m in a natural depression separated from the outer sea by a natural low limestone ridge. Multibeam survey suggests that the present-day bay was originally subdivided into three smaller bays at the time of prehistoric occupation. The prehistoric settlement remains extend over an area of about $6500 \mathrm{~m}^{2}$. So far over 100 wooden stakes have been discovered, many of them vertically driven into deposits of peat and clay (Fig. 18.7). They are concentrated in the north-western corner of the depression and have been interpreted as piles to stabilise dwelling structures located on marshy ground close to the original shoreline. Koncani Uhač and Čuka (2016) report the presence in the sediments of aquatic plant remains such as alkali bulrush (Scirpus maritimus L.), hairy sedge (Carex cf. hirta L.), pondweed (Potamogeton sp.), and water caltrop (Trapa natans L.), and more detailed analysis of the palaeolandscape is ongoing. ${ }^{1}$ Other material recovered from the cultural layers comprises pottery, including 300 diagnostic sherds of the Early Eneolithic Nakovana culture, several round spindle whorls, and animal bones.

\subsubsection{Other Finds}

Three other Istrian sites have provided underwater evidence, including pottery and faunal remains, attributed to the Eneolithic period. One is in the shallow bay of Veruda south of Pula where dredging of the harbour recovered two polished axe heads made of volcanic rocks, chipped stone artefacts made of local dark chert, and a shaft-hole axe (Fig. 18.8; Mihovilić 1992, 1995a, b; Benjamin et al. 2011). At the second site on the shore of Cape Gale in Peroj, potsherds, some 500 stone artefacts made on chert, other stone tools, and faunal remains have been found in the intertidal zone to a depth of c. $0.5 \mathrm{~m}$. However, their status as evidence of a submerged settlement is unclear since they could have been eroded from a settlement located on the presentday shoreline. Finally, five pieces of chert, of which one is a probable tool, at a depth of 1.5$2.5 \mathrm{~m}$, indicate a possible underwater site, maybe from the same period, in the bay of Veštar (Benjamin et al. 2011, p. 195).

Elsewhere, Eneolithic material found underwater is limited to chance finds of limited material or uncertain provenance. These include pottery fragments found beneath a c. 200-year-old wooden ship's hull between the islands of Oruda and Palacol at a depth of $5 \mathrm{~m}$ (Mihajlović 2011;

${ }^{1}$ The palaeolandscape study is being carried out as a $\mathrm{PhD}$ topic by Katarina Jerbić at Flinders University, Australia. 
Fig. 18.6 Early

Neolithic impresso potsherds from

Čvrljevića Ograda. Scale in cm. After Batović (1965)

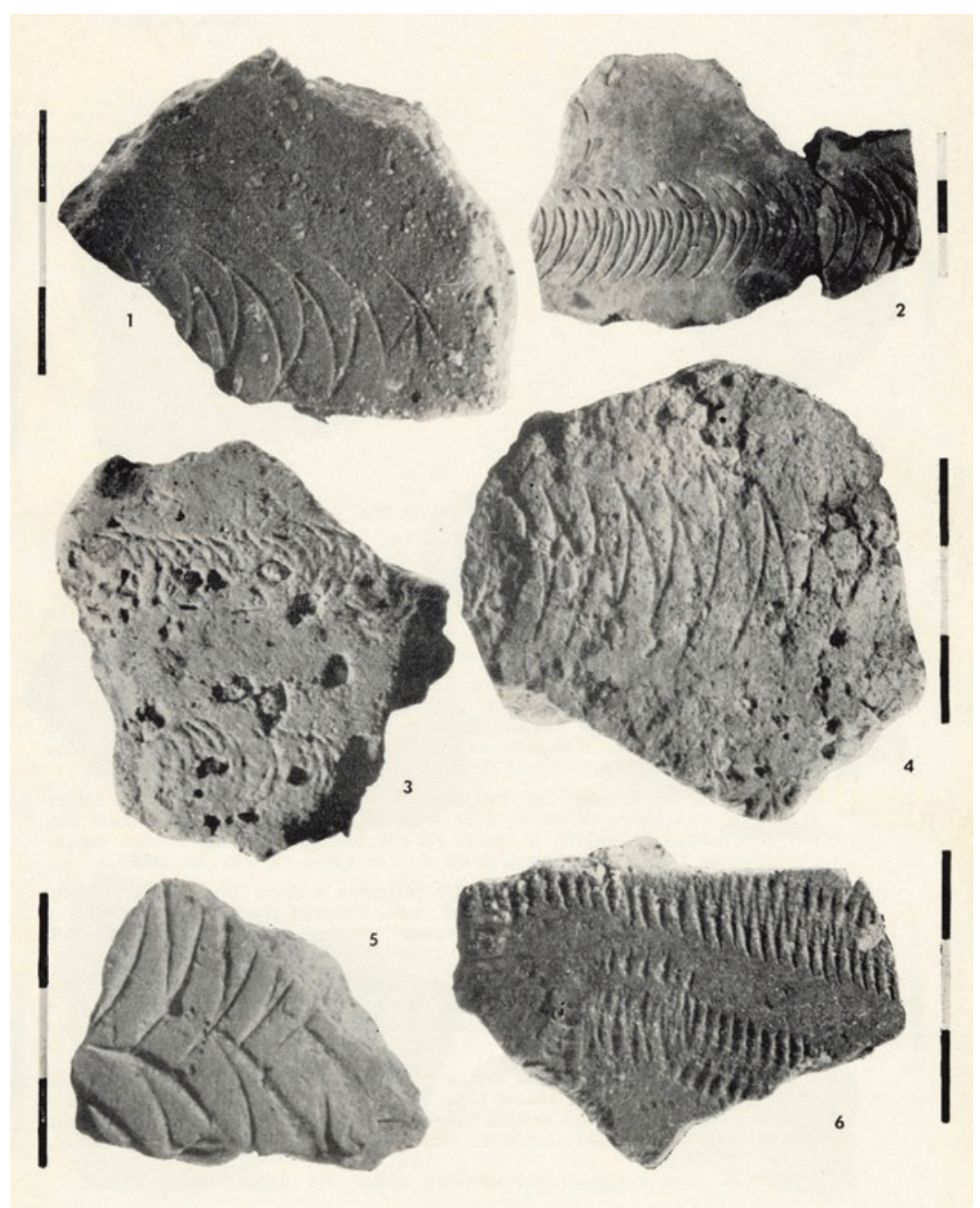

Benjamin et al. 2011) and long chert blades and core fragments disturbed by ship propellers at a depth of 5-6 $\mathrm{m}$ at Baška Voda near Makarska (Zubčić 2004; Benjamin and Črešnar 2009; Benjamin et al. 2011). Perhaps the most intriguing find is a submerged structure at Ljubačka Vala $2.6 \mathrm{~m}$ below present sea level east of the Gulf of Nin (Parica and Ilkić 2017). There are two embankments made of branches and rocks, the longer extending for $100 \mathrm{~m}$, and this has been interpreted as a fish trap. Radiocarbon dating indicates a Late Eneolithic/Early Bronze Age date.

One other find to mention is a complete globular ceramic vessel of Late Eneolithic/Early Bronze Age date dredged up from a depth of
$30 \mathrm{~m}$ in the Gulf of Marina (Fig. 18.9; Radić Rossi 2011). The precise location was not recorded, but the pot must presumably represent an object lost overboard during sea travel or perhaps an item lost along with the rest of the cargo in a shipwreck or possibly a votive offering.

\subsubsection{The Bronze Age}

Submerged evidence notably increases with the Bronze and Iron Ages with a number of apparently well-preserved coastal sites close to the present-day shoreline that have been submerged by later sea-level rise. 


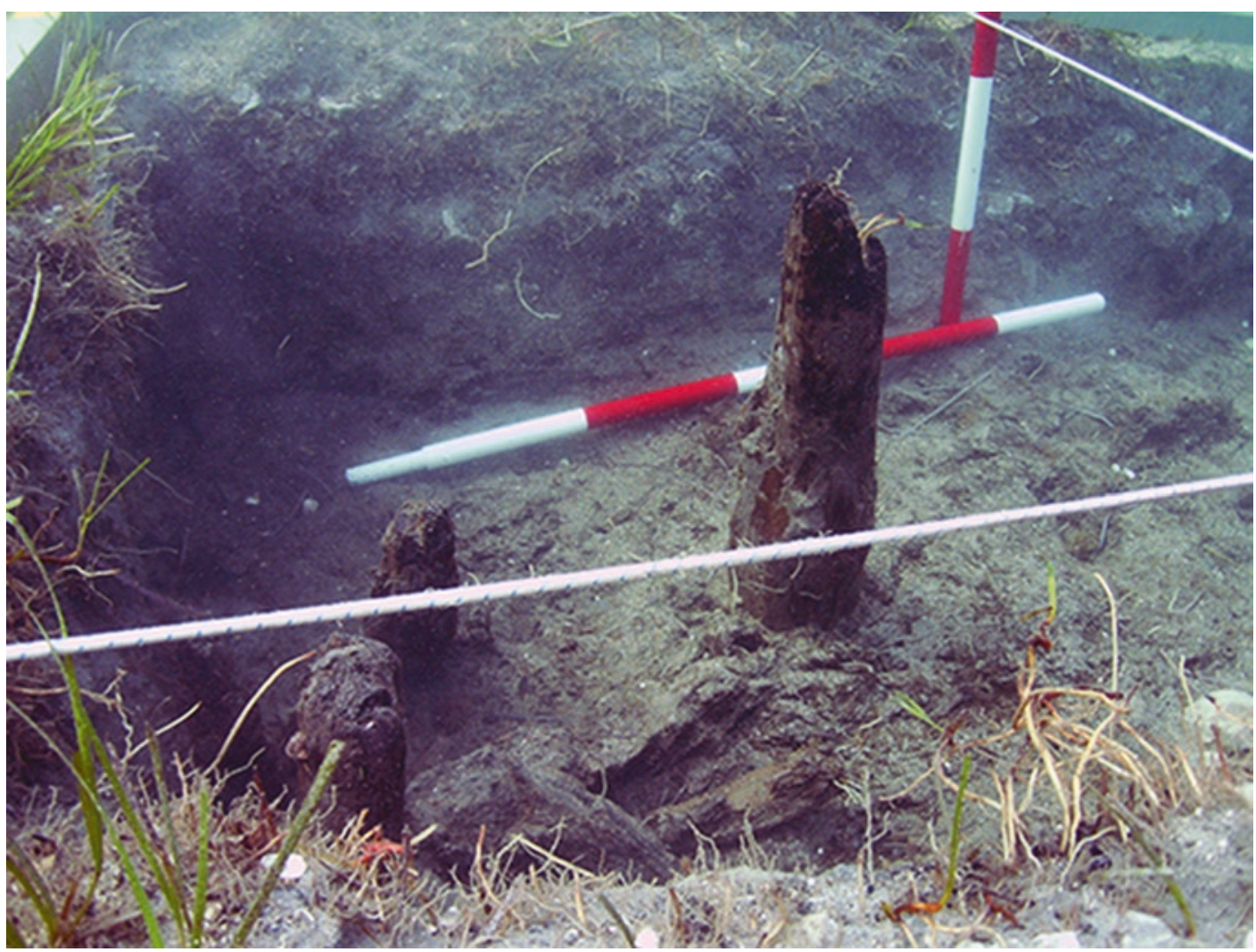

Fig. 18.7 View of the Eneolithic settlement area at Zambratija showing oak piles used in the construction of wooden structures. Scale in $20 \mathrm{~cm}$ units. After Koncani Uhač and Čuka 2016. Photo courtesy of the authors

\subsubsection{The Pašman Channel: Ričul and Oštarije}

Ričul is located off the north-east shore of a small island in the Pašman Channel (Fig. 18.10). Brusić (1977) first identified a humus layer at a depth of 2-3 m, with abundant sherds of prehistoric pottery, marine shells and animal bones, and an artificial causeway at a depth of 1.5-3 m made of cobbles and massive timbers to provide a connection between the island and the mainland.

New investigations began in 2012 followed by excavations (Čelhar et al. 2017). The new research confirmed the existence of a 125-m-long linear structure connecting the island to the mainland and also identified a lateral embankment built of wooden stakes driven into the original gravel beach and consolidated with cobbles, stone slabs, and potsherds (Fig. 18.11). The top of the embankment now lies at $-2.2 \mathrm{~m}$ and the seabed at $-3-4 \mathrm{~m}$, and the excavators interpreted it as an artificial structure built to protect the settlement from rising sea level. The settlement covers an area of 1 ha, but a large part of it has been destroyed by gravel extraction. Pottery (Fig. 18.12) and radiocarbon dates indicate a Middle Bronze Age date, c. 3.5-3.3 ka cal BP.

Oštarije (Kumentić) is $5 \mathrm{~km}$ to the south-east and is near a small island c. $200 \mathrm{~m}$ offshore from the mainland near Crvena Luka. The intervening channel is no deeper than $2.5 \mathrm{~m}$ and formed a dry connecting causeway during the Bronze Age. The settlement comprises structures with drywall foundations or carved into the rock at depths of 1.5-2 m below sea level, and the pottery is similar to the finds from Ričul (Brusić 1977). 


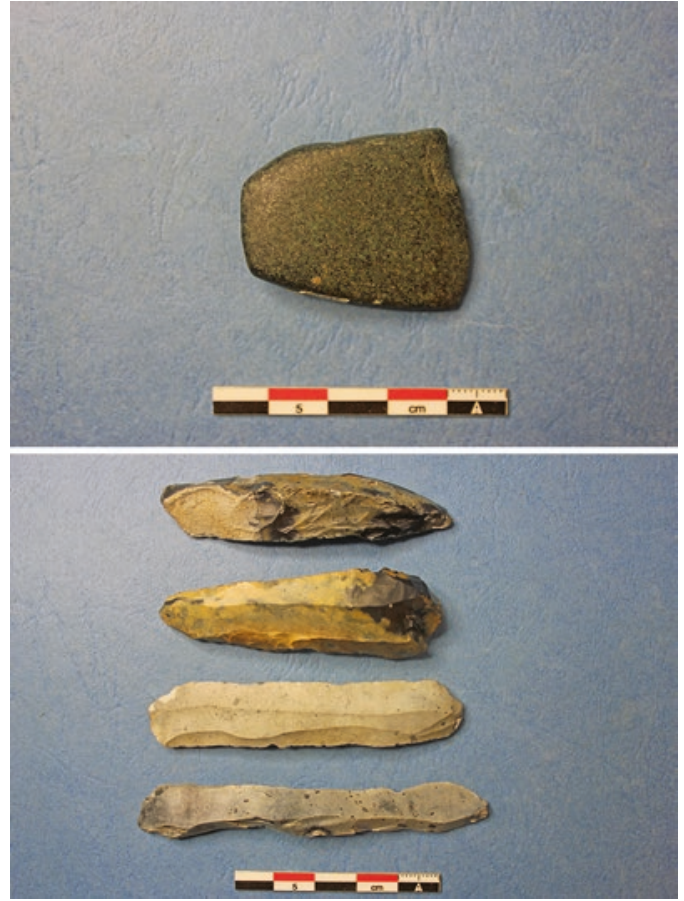

Fig. 18.8 Artefacts from Pula-Veruda. (Upper) Stone shaft-hole axe. (Lower) Selection of blades made on local chert. Scale in $\mathrm{cm}$. Courtesy of the Archaeological Museum of Istria, Pula

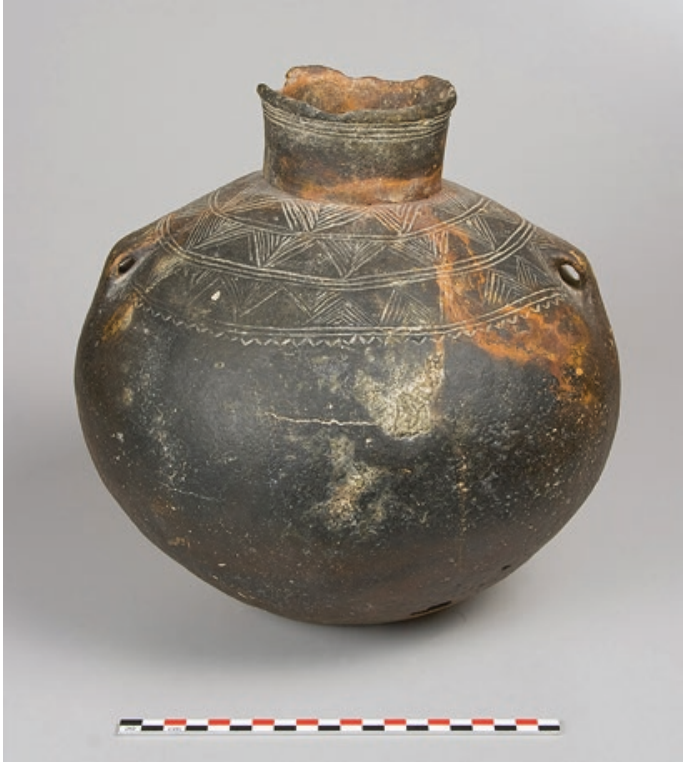

Fig. 18.9 Globular vessel recovered from a depth of $30 \mathrm{~m}$ in the Gulf of Marina. The vessel is made of fine ware with incised decoration on the cylindrical neck and the upper part of the body. This is in the style of LjubljanaAdriatic pottery of the Late Eneolithic/Early Bronze Age (Table 18.1; Forenbaher 2018b). Photo by Damil Kalogjera

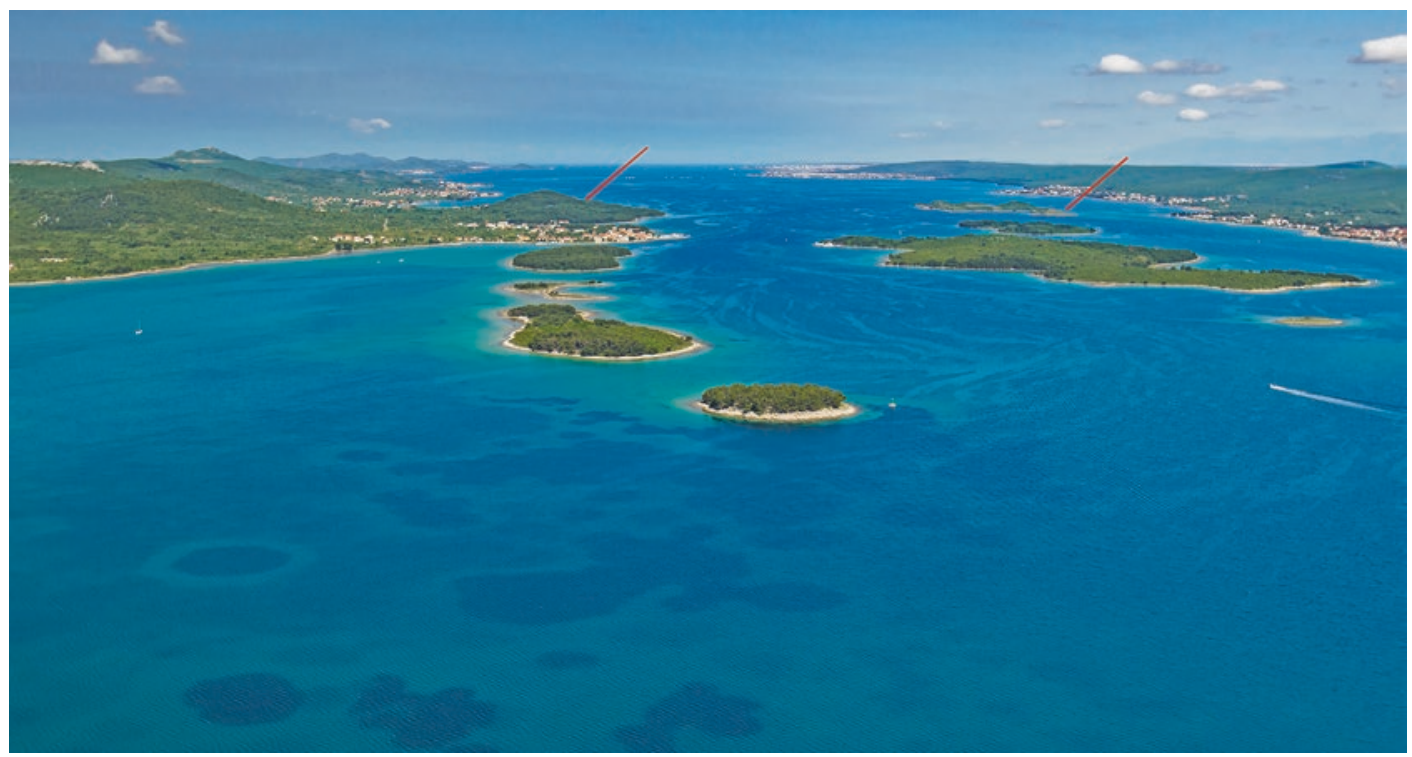

Fig. 18.10 Aerial view of the Pašman Channel looking north-west, with the position of the underwater Bronze Age Ričul site shown by a red arrow on the right and the underwater Iron Age site of Garmenjak near the island of Pašman on the left. Photo by Ervin Šilić 


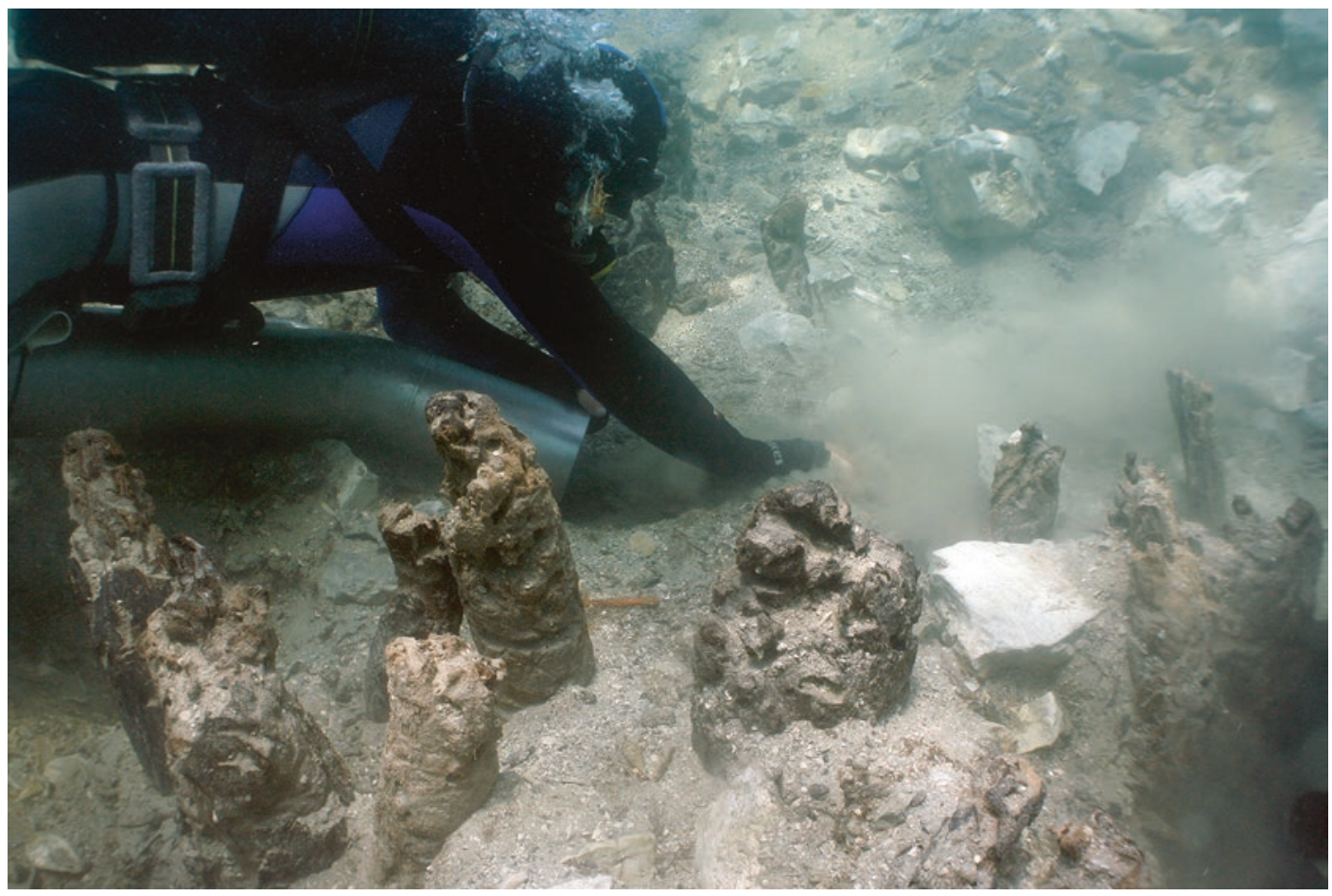

Fig. 18.11 Concentration of wooden poles at the site of Ričul, interpreted as part of an artificial embankment. Photo by Mate Parica

Judging by the number of sites on both sides of the Pašman Channel including Bronze Age settlements, Iron Age hillforts, and the submerged sites of Pakoštane Ričul and Oštarije, the region was clearly an important focus of settlement throughout later prehistory and increasingly an important seafaring route and a centre for controlling access, movement, and exchange of goods between central and northern Dalmatia. The combination of further work on the submerged sites together with studies of the nearby Vrana Lake (Ilijanić et al. 2018) also offer promising prospects for new palaeoenvironmental investigations.

\subsubsection{Other Sites}

Elsewhere, mention should be made of the Vranjic Peninsula in the Gulf of Kaštela, where rescue excavations salvaged remains of a Bronze
Age settlement and a stratigraphic profile showing changes in the coastal environment over a 3000-year period (Radić Rossi 2008; (Arena et al. forthcoming). In the Bay of Šimuni on the island of Pag, remains of a submerged coastal settlement at a depth of 2-3 m have recently been discovered with rows of wooden stakes and numerous potsherds (Bekić 2017). Submerged Bronze Age material has also been found in the anchialine cave of Živa Voda on the island of Hvar (Figs. 18.13, 18.14; Radić Rossi and Cukrov 2017). As on land, so underwater, there is evidence of continuity from the Bronze Age to the Iron Age because of a continuing rise in relative sea level. The most distinctive submerged Iron Age finds so far discovered are the burials of the Liburnian period at $\mathrm{Nin}$ and on the island of Murter (Brusić 1969, 2002, 2005). 


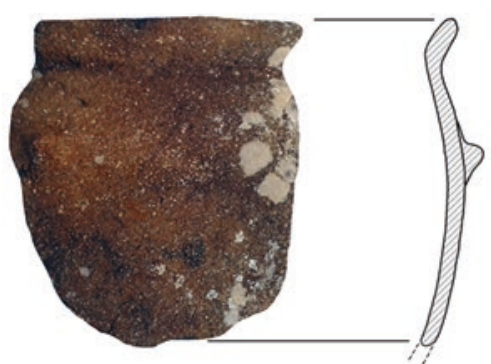

1

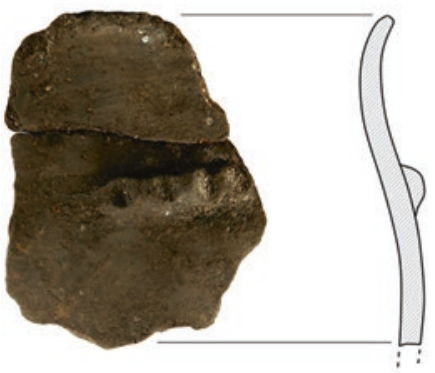

3

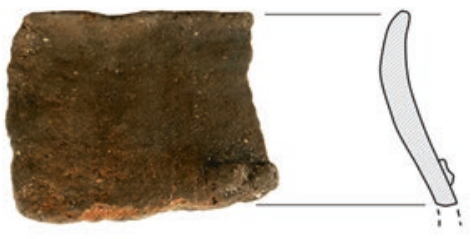

5

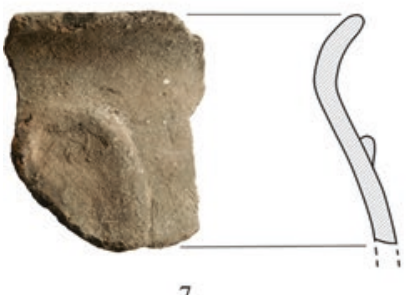

7

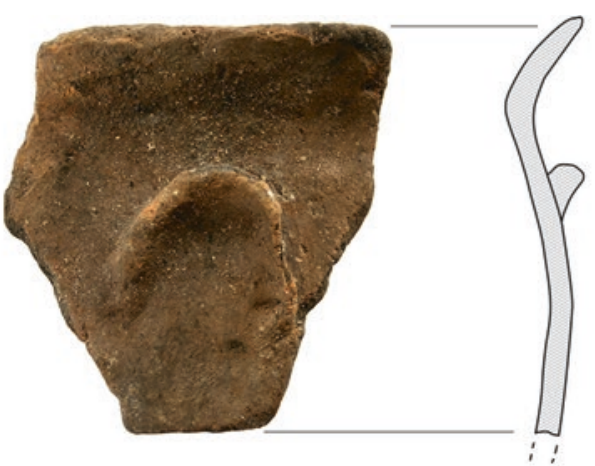

2

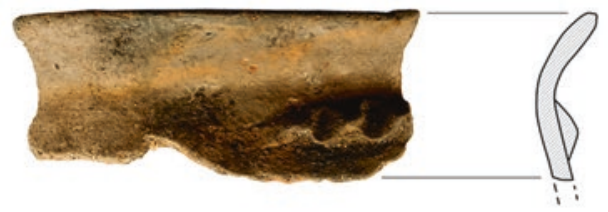

4

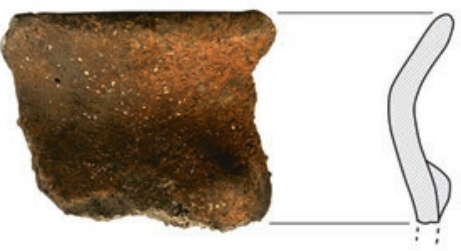

6

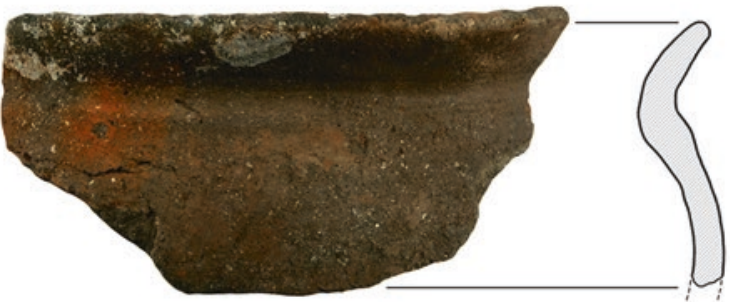

8

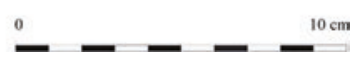

Fig. 18.12 Selection of Bronze Age pottery at Ričul showing characteristic features. Photos by Mate Parica; drawings by Dario Vujević 


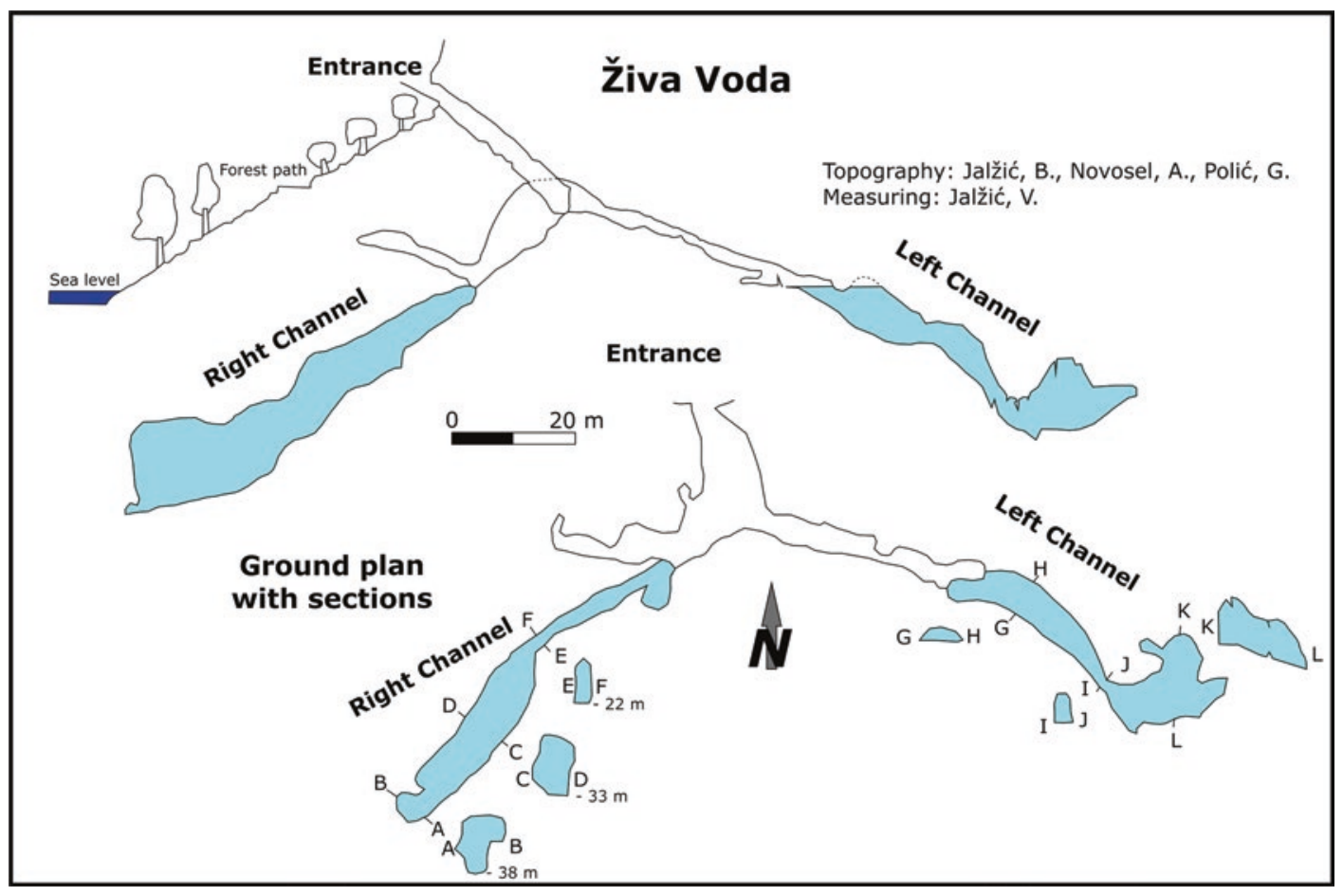

Fig. 18.13 Plan and cross section of the cave of Živa Voda cave on the island of Hvar. This is an anchialine cave, that is, a cave with a submarine connection to the sea and a stratified water column with fresh water at the surface. These are important sources of fresh water. Potsherds of Bronze Age or later periods have been recovered by speleologists from the left channel of this cave system, but it has not been archaeologically researched (Radić Rossi and Cukrov 2017). Drawing by Branko Jalžić, Anđelko Novosel, Gordan Polić, and Vedran Jalžić

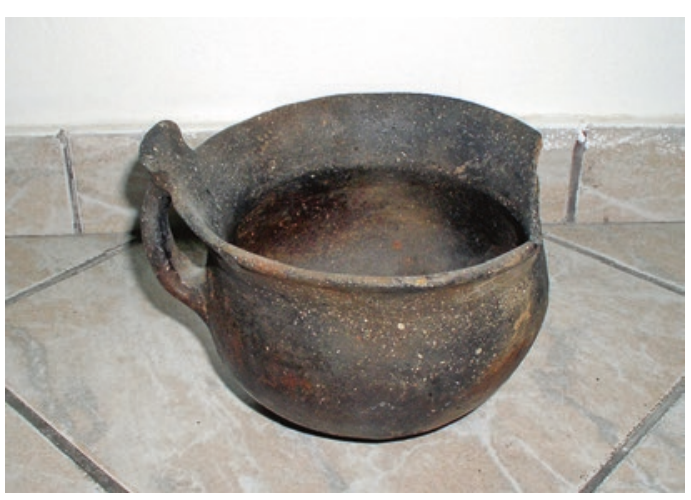

Fig. 18.14 Bronze Age ceramic bowl recovered from the left channel of Živa Voda cave on the island of Hvar. The diameter of the bowl is c. $20 \mathrm{~cm}$. Photo by Irena Radić Rossi

\subsection{Conclusion: Future Challenges and Management of the Underwater Heritage}

The above account highlights the chronological range, variety, and potential significance of submerged prehistory in Croatia. Because of sinking coastlines in recent millennia, added to the effects of postglacial sea-level rise, underwater prehistoric finds range in age from the deeply submerged Middle Pleistocene mammoth remains of Pag and the Mousterian artefacts of Resnik to burials and settlements of the Iron Age. Moreover, because of its mountainous topography and the 
emphasis throughout its long history of human settlement on coastal regions, shorelines, offshore islands, and sea travel, the importance of underwater research in filling gaps in the prehistoric record of Croatia cannot be overemphasised.

Although discoveries of intertidal and submarine prehistoric archaeology have quite a long history, systematic research has only been initiated or intensified in the past decade. Most of the better-preserved sites described above have received only test excavations or partial postexcavational analysis of the cultural and palaeoenvironmental material. Thus, there is clearly scope for new research and new archaeological discoveries, especially in combination with palaeoenvironmental and palaeoclimatic analysis of submerged landscapes and sediments.

Some of the important discoveries were made as a result of construction work in the coastal zone, which has exposed the archaeological evidence to view but also contributed to its destruction, resulting in hasty salvage operations and the loss of much valuable information. One of the major challenges for the future is to ensure a better integration of policies on heritage protection, commercial and industrial development, and scientific research.

At present, the main government agency responsible for protection and management of the underwater (and terrestrial) cultural heritage and for the issue of permits for field research is the Ministry of Culture of the Republic of Croatia. Implementation is delegated to regional conservation offices in Pula, Rijeka, Gospić, Zadar, Šibenik, Trogir, Split, and Dubrovnik. Financial support is shared between the Ministry of Culture, the Croatian Science Foundation, and the local communities. The principal organisations involved in research and site protection are the Department of Archaeology of the University of Zadar, the Archaeological Museum of Zadar, the UNESCO II Category Centre for Underwater Archaeology in Zadar, the Archaeological Museum of Istria in Pula, the Department of Archaeology of the Faculty of Humanities and Social Sciences, University of Zagreb, and the Department of Underwater Archaeology of the Croatian Conservation Institute in Zagreb. Thus, there is considerable expertise in systematic research and management of the underwater cultural heritage and examples of good practice.

However, despite the fact that Croatia is a signatory to the UNESCO 2001 Convention on the Protection of the Underwater Heritage, there is a need to develop formal systematic procedures for the public assessment of plans for construction work that may impact scientifically valuable underwater remains of prehistoric archaeology and features of the submerged landscape (see Pater, Chap. 27 this volume, and the chapters in Part I and Part II of this volume). Formal procedures need to be developed to ensure implementation of mitigation work or protection of the more insubstantial remains typical of prehistoric archaeological material and submerged landscapes and to achieve better integration with scientific research, in line with practices that have been developed in other European countries.

Acknowledgements Research on underwater Croatian prehistoric sites was mainly funded by the Ministry of Culture of Republic of Croatia and by the Croatian Science Foundation through the research projects IP-09.01/320 (Late Mousterian in the eastern Adriatic towards understanding of the late Neanderthals' identity and their demise) and IP-09-2014-8211 (Archaeology of Adriatic Shipbuilding and Seafaring - AdriaS). We express our gratitude to Alberta Arena, Neven Cukrov, Martina Čelhar, Stašo Forenbaher, Branko Jalžić, Darko Komšo, Ida Koncani Uhač, Jadranka Mauh Lenardić, Marko Meštrov, Mate Parica, Petronije Tasić, and Dario Vujević for their precious help in completing and illustrating this chapter. We are also indebted to Geoff Bailey for his suggestions, comments, and editing of this paper.

\section{References}

Antonioli F, Anzidei M, Lambeck K, Auriemma R, Gaddi D, Furlani S, Orrù P, Solinas E, Gaspari A, Karinja S, Kovačić V, Surace V (2007) Sea-level change during the Holocene in Sardinia and in the Northeastern Adriatic (Central Mediterranean Sea) from archaeological and geomorphological data. Quat Sci Rev 26:2463-2486

Arena A, Barbarić V, Radić Rossi I (forthcoming) Vranjic (Kaštela Bay) between the late Early and the Middle Bronze Age (19th-14th century BCE). In: Okolica Kaštelanskog zaljeva u Prošlosti, Proceedings of the Symposium of the Croatian Archaeological Society, Kaštel Lukšić, 2-6 October 2017 
Barbir A (2015) Litički materijal s podvodnog srednjopaleolitičkog nalazišta Kaštel Štafilić - Resnik, Graduate thesis. University of Zagreb, Faculty of Humanities and Social Sciences, Zagreb

Batović Š (1965) Neolitski ostaci iz Nina i njihov položaj u okviru neolita na Mediteranu. Diadora 3:5-40

Batović Š (1988) Paleolitički i mezolitički ostaci s Dugog otoka. Poročilo o raziskovanju paleolita, neolita in eneolita v Sloveniji 16:7-54

Batović Š (1990a) Novija istraživanja prapovijesti u biogradskom kraju. In: Batović Š, Obad S, Jakšić N, Došen B, Božulić G (eds) Biograd i njegova okolica u prošlosti. Zavod za povijesne znanosti Filozofskog fakulteta u Zadru, pp 85-171

Batović Š (1990b) Rekognosciranje Otoka Paga u 1989. godini. Obavijesti Hrvatskog arheološkog društva $1: 26-32$

Bekić L (2017) Šimuni, novo podvodno brončanodobno nalazište u Zadarskoj županiji / Šimuni, New Bronze Age Underwater Site in Zadar County. Diadora 31:41-50

Bekić L, Ilkić M, Brusić Z, Meštrov M, Parica M, Pešić M, Scholz R (2011) New Underwater archaeological research in Pakoštane near Zadar / Nova podvodna arheološka istraživanja u Pakoštanima kod Zadra. Submerged Heritage / Potopljena baština 1:25-31

Bekić L, Pešić M, Scholz R, Meštrov M (2016) Podvodna arheološka istraživanja na prapovijesnom nalazištu Pakoštane - Janice / Underwater archaeological research at the prehistoric site of Pakoštane - Janice. Diadora 29:7-22

Benac Č, Juračić M (1998) Geomorphological indicators of the sea level changes during Upper Pleistocene (Wurm) and Holocene in the Kvarner region (NE Adriatic Sea). Acta Geographica Croatica 33(1):27-45

Benac Č, Juračić M, Bakaran-Petricioli T (2004) Submerged tidal notches in Rijeka Bay NE Adriatic Sea: indicators of relative sea-level change and of recent tectonic movements. Mar Geol 212:21-33

Benac Č , Juračić M, Blašković I (2008) Tidal notches in Vinodol Channel and Bakar bay: Indicators of recent tectonics. Mar Geol 248:151-160

Benjamin J, Črešnar M (2009) Submerged prehistoric site discovery and a proposed application in the Croatian Adriatic. In: Bekić L (ed) Jurišićev zbornik. Hrvatski restauratorski zavod. Međunarodni centar za podvodnu arheologiju u Zadru, Zagreb, pp 52-67

Benjamin J, Bekić L, Komšo D, Koncani Uhač I, Bonsall C (2011) Investigating the submerged prehistory of the Eastern Adriatic: progress and prospects. In: Benjamin J, Bonsall C, Pickard C, Fischer A (eds) Submerged prehistory. Oxbow, Oxford, pp 193-206

Benjamin J, Rovere A, Fontana A, Furlani S, Vacchi M, Inglis RH, Galili E, Antonioli F, Sivan D, Miko S, Mourtzas N, Felia I, Meredith-Williams M, GoodmanTchernov B, Kolaiti E, Anzidei M, Gehrels R (2017) Late Quaternary sea-level changes and early human societies in the central and eastern Mediterranean Basin: An interdisciplinary review. Quat Int 449:29-57
Bognar A, Faivre S, Buzjak N, Pahernik M, Bočić N (2012) Recent landform evolution in the Dinaric and Pannonian regions of Croatia. In: Lóczy D, Stankoviansky M, Kotarba A (eds) Recent landform evolution - The Carpatho-Balkan-Dinaric Region. Springer, Dordrecht, pp 313-344

Brusić Z (1969) Rezultati podvodnih istraživanja u Ninu. Mornarički glasnik 22:218-222

Brusić Z (1977) Prehistorijski podmorski nalazi na području južne Liburnije. Radovi Centra Jugoslavenske Akademije Znanosti i Umjetnosti u Zadru 24:53-60

Brusić Z (2002) Nekropole liburnskih naselja Nina i Kose kod Ljupča. Histria Antiqua 8:213-242

Brusić Z (2004) Resnik - hidroarheološka istraživanja, katalog izložbe. Muzej grada Kaštela, Kaštela

Brusić Z (2005) Arheološki spomenici otoka Murtera. Murterski godišnjak 2/2004:91-101

Brusić Z, Parica M (2014) Ljubač - liburnsko pristanište. Hrvatski arheološki godišnjak / Croatian Archaeological Yearbook 10/2013:467-468

Bulić F (1898) Ritrovamenti antichi risguardanti la topografia urbana dell'antica Salona. Bulletino di archeologia e storia dalmata 21:157-159

Cancellieri E (2011) From the watershed to the Great Adriatic Plain: an investigation on humans and landscape ecology during the late Upper Paleolithic. The significance of lithic technology. Dissertation Università degli Studi di Ferrara, Ferrara

Čelhar M, Parica M, Ilkić M, Vujević D (2017) A Bronze Age underwater site near the islet of Ričul in northern Dalmatia (Croatia). Skyllis 17(1):21-34

Duplančić Leder T, Ujević T, Čala M (2004) Coastline lengths and areas of islands in the Croatian part of the Adriatic Sea determined from the topographic maps at the scale of 1:25 000. Geoadria 9(1):5-32

Fairbridge RW (1968) The Encyclopedia of geomorphology. Reinhold Book, New York

Faivre S, Butorac V (2018) Recently submerged tidal notches in the wider Makarska area (Central Adriatic, Croatia). Quat Int 494:225-235

Faivre S, Fouache E, Kovačić V, Glušćević S (2010) Geomorphological and archaeological indicators of Croatian shoreline evolution over the last two thousand years. Geo Acta 3:125-133

Faivre S, Fouache E, Ghilardi M, Antoniloli F, Furlani S, Kovačić V (2011) Relative sea level change in western Istria (Croatia) during the last millenium. Quat Int 232:132-143

Faivre S, Bakran-Petricioli T, Horvatinčić N, Sironić A (2013) Distinct phases of relative sea level changes in the central Adriatic during the last 1500 years influence of climatic variations? Palaeogeogr Palaeoclimatol Palaeoecol 369:163-174

Fernández Á (2003) Shell beads of the last huntergatherers and earliest farmers in south-western Europe. Munibe 61:129-138

Florido E, Auriemma R, Faivre S, Radić Rossi I, Antonioli F, Furlani S, Spada G (2011) Istrian and Dalmatian fishtanks as sea-level markers. Quat Int 232:105-113 
Forenbaher S (2011) Adriatic offshore islands and longdistance interaction in prehistory. In: Forenbaher S (ed) A connecting sea: maritime interaction in Adriatic prehistory, BAR International Series, vol 2037. Archaeopress, Oxford, pp 73-87

Forenbaher S (2018a) Special place, interesting times: The island of Palagruža and transitional periods in Adriatic prehistory. Archaeopress, Oxford

Forenbaher S (2018b) Ljubljana and Cetina: Pottery styles of the Third Millennium BC in the Eastern Adriatic. Prilozi instituta za arheologiju 35:113-158

Forenbaher S, Kaiser T (2005) Palagruža and the spread of farming in the Adriatic. Opuscula archaeologica 29:7-23

Forenbaher S, Miracle P (2006) The spread of farming in the Eastern Adriatic. Documenta Praehistorica 33:589-609

Forenbaher S, Kaiser T, Miracle P (2013) Dating the East Adriatic Neolithic. Eur J Archaeol 16(4):589-609

Furlani S, Cucchi F, Biolchi S, Odorico R (2011) Notches in the Northern Adriatic Sea: genesis and development. Quat Int 232:158-168

Glogović D (1989) Prilozi poznavanju željeznog doba na Sjevernom Jadranu. Hrvatsko Primorje i otoci. Jugoslavenska akademija znanosti i umjetnosti, Zagreb

Ilijanić N, Miko S, Hasan O, Marković T (2018) Geological, structural-tectonic and hydrogeological characteristics of the Pakoštane area and Lake Vrana. In: Radić Rossi I, Boetto G (eds) Pakoštane - Veli Školj: The Late Roman shipwreck in its geologicalgeographic and cultural-historical context. University of Zadar \& Institute for Maritime Heritage ARS NAUTICA, Zadar, pp 161-177

Janković I, Mihelić S, Karavanić I (2011) Put neandertalaca / The Neandertal Trail. Arheološki muzej u Zagrebu, Zagreb

Kamenjarin I, Šuta I (2011) Antički Sikuli / Ancient Siculi, exhibition catalogue. Museum of the Town of Kaštela, Kaštel Lukšić

Karavanić I (2000) Research on the Middle Palaeolithic in Dalmatia, Croatia. Antiquity 74:777-778

Karavanić I (2004) The Middle Palaeolithic settlement of Croatia. In: Conard NJ (ed) Settlement dynamics of the Middle Palaeolithic and Middle Stone Age, vol II. Kerns Verlag, Tübingen, pp 251-267

Karavanić I (2009) Adriatic coast of Croatia and its hinterland from 50000 to 25000 BP. In: Camps M, Szmidt $\mathrm{C}$ (eds) The Mediterranean from 50000 to $25000 \mathrm{BP}$ : Turning points and new directions. Oxbow Books, Oxford, pp 163-178

Karavanić I (2015) Research on underwater Mousterian: The site of Resnik - Kaštel Štafilić, Dalmatia, Croatia. In: Sázelová S, Novák M, Mizerová A (eds) Forgotten times and spaces: New perspectives in paleoanthropological, paleoetnological and archeological studies. Institute of Archeology of the Czech Academy of Sciences \& Masaryk University, Brno, pp 73-79

Karavanić I, Barbir A (2017) Underwater Palaeolithic sites in Croatia. In: 5th Regional Scientific Meeting on Quaternary Geology Dedicated to Geohazards and Final conference of the LoLADRIA project "Submerged Pleistocene landscapes of the Adriatic Sea", 9-10 November 2017, Starigrad-Paklenica, Croatia, Abstracts. Croatian Academy of Science and Arts, Zagreb, p 28

Karavanić I, Miracle PT, Culiberg M, Kurtanjek D, Zupanič J, Golubić V, Paunović M, Mauch Lenardić J, Malez V, Šošić R, Janković I, Smith FH (2008) The Middle Paleolithic from Mujina Pećina, Dalmatia, Croatia. J Field Archaeol 33:259-277

Karavanić I, Zubčić K, Pešić M, Parica M, Šošić Klindžić R (2009) Kaštel Štafilić - podvodno paleolitičko nalazište. Hrvatski arheološki godišnjak / Croatian Archaeological Yearbook 5/2008:549-551

Karavanić I, Vukosavljević N, Šošić Klindžić R, Kurtanjek D, Zupanič J (2013) The lithic and bone industries of the Epigravettian layers from Šandalja II near Pula. Vjesnik za arheologiju i povijest dalmatinsku 106:7-73

Karavanić I, Janković I, Ahern JCM, Smith FH (2014a) Current Research on the Middle Paleolithic Cave, Open-air and Underwater Sites in Dalmatia, Croatia. In: Sázelová S, Hupková A, Morkovsky T (eds) Mikulov Anthropology Meeting 2014, [The Dolní Věstonice Studies 20]. Academy of Sciences of the Czech Republic, Institute of Archeology, Brno and Masaryk University, Department of Anthropology, Brno, pp 31-36

Karavanić I, Vukosavljević N, Šošić Klindžić R, Ahern JCM, Čondić N, Becker R, Zubčić K, Šuta I, Gerometta K, Boschian G (2014b) The Late Mousterian in the eastern Adriatic - towards understanding of late Neanderthals' identity and their demise project: a summary of the 1st year of research. Prilozi Instituta za arheologiju u Zagrebu 31:139-157

Karavanić I, Šošić Klindžić R, Ahern JCM, Čondić N, Janković I, Zubčić K, Smith FH (2015) Recent research on the Croatian Middle/Upper Paleolithic interface in the context of Central and Southeast Europe. In: Harvati K, Roksandić M (eds) Human evolution in the Southern Balkans. Springer, Dordrecht, pp 153-169

Kelletat DH (2005) Dalmatian coasts. In: Schwartz M (ed) Encyclopedia of coastal science, Encyclopedia of Earth Sciences Series. Springer, Dordrecht, pp 355-356

Komšo D (2008) The Mesolithic in Croatia. Opvscula archaeologica 30(2006):55-91

Komšo D, Vukosavljević N (2011) Connecting coast and inland: perforated marine and freshwater snail shells in the Croatian Mesolithic. Quat Int 244:117-125

Koncani Uhač I (2009) Podvodna arheološka istraživanja u uvali Zambratija. Histria Antiqua 17:263-268

Koncani Uhač I, Čuka M (2016) Doprinos poznavanju podmorskog eneolitičkog nalazišta u uvali Zambratija. Histria archaeologica 4:25-74

Koncani Uhač I, Boetto G, Uhač M (2017) Zambratija prehistoric sewn ship. Archaeological Museum of Istria, Pula 
Korbar T, Montanari A, Koch G, Mariani S, DePaolo D, Turchyn AV, Miknić M, Tari V (2009) Geologic reconnaissance of the island of Velika Palagruža (central Adriatic, Croatia). Geologia Croatica 62/2:75-94

Krile I, Vujević D (2017) A contribution to the study of early prehistory of Veli Rat on the island of Dugi Otok. Diadora 31:7-26

Lambeck K, Purcell A (2005) Sea-level change in the Mediterranean Sea since the LGM: model predictions for tectonically stable areas. Quat Sci Rev 24(18-19):1969-1988

Lambeck K, Woodroffe CD, Antonioli F, Anzidei M, Roland Gehrels W, Laborel J, Wright AJ (2010) Paleoenvironmental records, geophysical modeling and reconstruction of sea-level trends and variability on centennial and longer timescales. In: Church JA, Philip L, Woodworth PL, Aarup T, Wilson WS (eds) Understanding sea-level rise and variability. WileyBlackwell, Oxford, pp 64-121

Lambeck K, Antonioli F, Anzidei M, Ferranti L, Leoni G, Scicchitano G, Silenzi S (2011) Sea level change along the Italian coast during the Holocene and projections for the future. Quat Int 232:250-257

Lončar N, Bar-Matthews M, Ayalon A, Surić M, Faivre S (2017) Early and mid-Holocene environmental conditions in the eastern Adriatic recorded in speleothems from Mala špilja Cave and Velika špilja cave (Mljet island, Croatia). Acta carsologica 46.2/3:229-249

Lončar N, Bar-Matthews M, Ayalon A, Faivre S, Surić M (2018) Holocene climatic conditions in the eastern Adriatic recorded in stalagmites from Strašna peć Cave (Croatia). Quaternary international. https://doi. org/10.1016/j.quaint.2018.11.006

Majnarić Pandžić N (1998) Brončano i željezno doba. (Dimitrijević S, Težak Gregl T, Majnarić Pandžić N, eds). Prapovijest. Naprijed, Zagreb, pp 161-169

Malez M (1979) Nalazišta paleolitskog i mezolitskog doba u Hrvatskoj. In: Basler Đ (ed) Praistorija Jugoslavenskih Zemalja; Paleolit i Mezolit. Svjetlost, Sarajevo, pp 227-276

Malez M, Lenardić-Fabić J (1988) New subspecies of the southern elephant (Mammuthus meridionalis adriacus n. sp.) from the bottom of the Adriatic Sea (Croatia, Yugoslavia). Palaeontol Jugoslav 37:1-36

Marriner N, Morhange C, Faivre S, Flaux C, Vacchi M, Miko D, Dumas V, Boetto G, Radić Rossi I (2014) Post-Roman sea-level changes on Pag Island (Adriatic Sea): Dating Croatia's "enigmatic" coastal notch? Geomorphology 221:83-94

Mauch Lenardić J (2012) Miocene to late Pleistocene proboscideans of Croatia. Quat Int 276-277:120-128

Mihailović D (2009) Upper Paleolithic and Mesolithic chipped stone industries from Crvena Stijena. Prehistoric settlements in caves and rock-shelters of Serbia and Montenegro. Fascicule II. University of Belgrade, Belgrade

Mihailović D, Whallon R (2017) Crvena Stijena revisited: the late Mousterian assemblages. Quat Int 450:36-49
Mihajlović I (2011) Podmorje Kvarnera (Oruda, Unije). Hrvatski arheološki godišnjak/Croatian Archaeological Yearbook 7/2010:480-481

Mihovilić K (1992) Bay of Veruda - Pula. Site of stone objects. Poročilo o Raziskovanju Paleolita, Neolita in Eneolita v Sloveniji 20:87-93

Mihovilić K (1995a) Prapovijesni lokaliteti obalne Istre. Histria Antiqua 1:58-63

Mihovilić K (1995b) Školjić (Funtana) i tragovi prapovijesnih obalnih i otočnih lokaliteta Istre. Histria archaeologica 26:28-57

Miko S, Ilijanić N, Hasan O, Razum I, Durn T, Brunović D, Papatheodorou G, Bakrač K, Hajek Tadesse V, Crmarić R (2016) Late Quaternary evolution of lakes and submerged paleo-karst on the Eastern Adriatic. In: Mandić O, Pavelić D, Kovačić M, Sant K, Andrić N, Hrvatović H (eds) RCMNS Interim Colloquium. Croatian Geological Society, Zagreb, pp 17-18

Miracle PT (1995) Broad-spectrum adaptations reexamined: Hunter-gatherer responses to Late-Glacial environmental changes in the Eastern Adriatic, $\mathrm{PhD}$ dissertation, University of Michigan

Miracle PT (2005) Late Mousterian subsistence and cave-use in Dalmatia: the zooarchaeology of Mujina Pećina, Croatia. Int J Osteoarchaeol 15:84-105

Mocochain L, Audra P, Clauzon G, Bellier O, Bigot JY, Parize O, Monteil P (2009) The effect of river dynamics induced by the Messinian Salinity Crisis on karst landscape and caves: example of the Lower Ardèche River (mid Rhone valley). Geomorphology 109(12):46-61

Moore AMT (2014) The spread of farming to the Adriatic: New insights from Dalmatia. In: Ammerman AJ, Davis TW (eds) Island archaeology and the origins of seafaring in the eastern Mediterranean. Proceedings of the Wenner-Gren Workshop held at Reggio Calabria on October 19-21, 2012. Eurasian Prehistory (1-2):155-164

Papagianni D (2009) Mediterranean southeast Europe in the Late Middle and Early Upper Palaeolithic: modern human route to Europe or Neanderthal refugium? In: Camps M, Szmidt C (eds) The Mediterranean from 50 000 to $25000 \mathrm{BP}$ : turning points and new directions. Oxbow Books, Oxford, pp 115-136

Papagianni D, Morse MA (2013) The Neanderthals rediscovered: how modern science is rewriting their story. Thames \& Hudson, New York

Parica M, Ilkić M (2017) Podmorski arheološki nalazi u okolici Ljupča. In: Faričić J, Lenkić J (eds) Župa Ljubač - zrcalo povijesnih i geografskih mijena $u$ sjeverozapadnom dijelu Ravnih Kotara. University of Zadar, Zdar, pp 98-111

Perhoč Z (2009) Sources of chert in Middle Dalmatia: Supplying raw material to prehistoric lithic industries. In: Forenbaher S (ed) A connecting sea: maritime interaction in Adriatic prehistory, BAR International Series 2037. Archaeopress, Oxford, pp 25-45

Pešić M (2012) Underwater archaeological research at the Janice site in Pakoštane / Podvodna arheološka 
istraživanja nalazišta Janice - Pakoštane. Submerged Heritage / Potopljena baština 2:39-43

Pešić M (2013) Research of the waters of the islet of Babuljaš near Pakoštane/Istraživanje podmorja otočića Babuljaša kod Pakoštana. Submerged Hertiage / Potopljena baština 3:25-30

Pikelj K, Juračić M (2013) Eastern Adriatic Coast (EAC): geomorphology and coastal vulnerability of a karstic coast. J Coast Res 29(4):944-957

Radić D (2011) The beginnings of trans-Adriatic navigation: a view from Vela Spila Cave (Korčula Island). In: Forenbaher S (ed) A connecting sea: maritime interaction in Adriatic prehistory, BAR International Series 2037. Archaeopress, Oxford, pp 13-24

Radić Rossi I (2008) Rescue excavations at Vranjic near Split, Croatia. In: Radić Rossi I, Gaspari A, Pydyn A (eds) Proceedings of the 13th annual meeting of the European Association of Archaeologists, Zadar, Croatia, 18-23 September 2007. Croatian Archaeological Society, Zagreb, pp 151-166

Radić Rossi I (2009) Arheološka baština u podmorju Kaštelanskoga zaljeva. Archaeologia Adriatica 2/2:489-506

Radić Rossi I (2011) Problematika prapovijesnih i antičkih nalazišta u hrvatskom podmorju, diss. University of Zadar, Zadar

Radić Rossi I, Antonioli F (2008) Preliminary considerations on the ancient port of Pakoštane (Croatia) based on archaeological and geomorphologic research. Book of abstracts; 14th Annual Meeting of the European Association of Archaeologists, 16-21 September 2008, Valetta, Malta, pp 96-97

Radić Rossi I, Boetto G (2013) Međunarodni istraživački projekt u uvali Caski na otoku Pagu; Prethodno izviješće o rezultatima istraživačke kampanje 2012. Histria Antiqua 22:377-390

Radić Rossi I, Cukrov N (2017) Archaeological potential of the anchialine caves in Croatia. In: Bailey GN, Harff J, Sakellariou D (eds) Under the sea: archaeology and palaeolandscapes of the continental shelf. Springer, Cham, pp 255-266

Radić Rossi I, Antonioli F, Spada G, Zubčić K, Meštrov M (2018) Sea level and shoreline changes in the Pakoštane area over the past six millennia. In: Radić Rossi I, Boetto G (eds) Pakoštane - Veli Školj: The Late Roman shipwreck in its geological-geographic and cultural-historical context. University of Zadar \& Institute for Maritime Heritage ARS NAUTICA, Zadar, pp 229-248

Rainsford C, O'Connor T, Miracle P (2014) Fishing in the Adriatic at the Mesolithic-Neolithic transition: Evidence from Vela Spila, Croatia. Environ Archaeol 19(3):311-320

Šegota T (1982) Razina mora i vertikalno gibanje dna Jadranskog mora od ris-virmskog interglacijala do danas. Geološki vjesnik 35:93-109

Šegota T (1983) Paleogeografske promjene u Jadranskom moru od Virmskog maksimuma do danas. Acta Geographica Croatica 17-18(1):11-14
Soura K, Geraga M, Papatheodorou G, Christodoulou D, Baika K, Kordella S, Fakiris E, Radić Rossi I, Boetto G, Zubčić K (2013) The study of palaeogeographic evolution of Caska Bay (Pag Island, Croatia) the last 10 kyrs using marine remote sensing techniques. In: SPLASHCOS: Under the Sea; Archaeology and Palaeolandscapes, Szczecin, Poland, 23-27 September 2013, Book of Abstracts. COST; European Cooperation in Science and Technology, Szcecin, p 27

Surić M (2009) Rekonstruiranje promjena morske razine na istočnoj obali Jadrana (Hrvatska) - pregled / Reconstructing sea-level changes on the Eastern Adriatic Sea (Croatia) - an overview. Geoadria 14/2:181-199

Surić M, Juračić M (2010) Late Pleistocene-Holocene environmental changes - records from the submerged speleothems along the Eastern Adriatic coast (Croatia). Geologia Croatica 63/2:155-169

Surić M, Juračić M, Horvatinčić N (2004) Comparison of C14 and Th230/U234 dating of speleothems from submarine caves in the Adriatic Sea (Croatia). Acta Carsologica 33(2):239-248

Surić M, Juračić M, Horvatinčić N, Krajcar Bronić I (2005) Late Pleistocene - Holocene sea-level rise and the pattern of coastal karst inundation - records from submerged speleothems along the Eastern Adriatic Coast (Croatia). Mar Geol 214:163-175

Surić M, Lončarić R, Lončar N (2010) Submerged caves of Croatia: distribution, classification and origin. Environ Earth Sci 61(7):1473-1480

Težak Gregl T (1998) Neolitik i eneolitik. (Dimitrijević S, Težak Gregl T, Majnarić Pandžić N, eds). Prapovijest. Naprijed, Zagreb, pp 57-158

Vlahović I, Tišljar J, Velić I, Matičec D (2002) The karst Dinarides are composed of relics of a single Mesozoic platform: facts and consequences. Geologia Croatica 55(2): $171-183$

Vlahović I, Tišljar J, Velić I, Matičec D (2005) Evolution of the Adriatic Carbonate Platform: Palaeogeography, main events and depositional dynamics. Palaeogeogr Palaeoclimatol Palaeoecol 220:333-360

Vrsalović D (2011) Arheološka istraživanja u podmorju istočnog Jadrana: prilog poznavanju trgovačkih plovnih putova i gospodarskih prilika na Jadranu u antici. Književni krug Split, Archaeological Museum of Split Vujević D (2009) The relationship between the Middle Palaeolithic sites in the Zadar hinterland and the Zadar Islands. In: Forenbaher S (ed) A connecting sea: Maritime interaction in Adriatic prehistory, BAR International Series 2037. Archaeopress, Oxford, pp 1-12

Vujević D, Parica M (2009) Nakit i umjetnost pećine Vlakno / Jewelery and Art of Vlakno Cave. Archaeologia Adriatica 3(1):23-34

Vujević D, Meštrov M (2018) Prehistoric lithic finds from the Janice site in Pakoštane. In: Radić Rossi I, Boetto G (eds) Pakoštane - Veli Školj: the late Roman shipwreck in its geological-geographic and culturalhistorical context. University of Zadar \& Institute 
for Maritime Heritage ARS NAUTICA, Zadar, pp 199-210

Vujević D, Perhoč Z, Ivančić T (2017) Micro-Mousterian in northern Dalmatia. Quat Int 450:50-67

Vukosavljević N, Karavanić I (2015) Kasnogornjopaleolitički i mezolitički ukrasi od probušenih morskih i slatkovodnih puževa iz špilje Zale. In: Vukosavljević N, Karavanić I (eds) Arheologija špilje Zale: od paleolitičkih lovaca skupljača do rimskih osvajača. Katedra Čakavskog sabora Modruše, Modruš, pp 157-174

Vukosavljević N, Perhoč Z, Čečuk B, Karavanić I (2011) Late Glacial knapped stone industry of Kopačina Cave. Vjesnik za arheologiju i povijest dalmatinsku 104:7-54

Vukosavljević N, Perhoč Z, Karavanić I (2015) Litički skup nalaza od lomljenog kamena iz špilje Zale: kasni gornji paleolitik I mezolitik. In: Vukosavljević N, Karavanić I (eds) Arheologija špilje Zale: od paleolitičkih lovaca skupljača do rimskih osvajača. Katedra Čakavskog sabora Modruše, Modruš, pp 73-118

Vuletić Vukasović V, Radić F (1887) Arheologičke bilježke s putovanja po otoku Korčuli u mjesecu svibnju 1887 god. Vjesnik Hrvatskog arheologičkog družtva 9:104-111

Whallon R (2007) Social territories around the Adriatic in the late Pleistocene. In: Whallon R (ed) Late Paleolithic environments and cultural relations around the Adriatic, BAR International Series 1716. Archaeopress, Oxford, pp 61-65

Zubčić K (2004) Novootkriveni prapovijesni podmorski nalazi u Baškoj vodi. Obavijesti Hrvatskog arheološkog društva 36/1:35-39

\section{Web Sources}

Croatian Ministry of the Sea, Transport and Infrastructure. http://www.mppi.hr/default.aspx?id=503. Accessed on 26 Feb 2019

Flanders Marine Institute (2018). IHO Sea Areas, version 3. Available online at http://www.marineregions.org/. https://doi.org/10.14284/323

Open Access This chapter is licensed under the terms of the Creative Commons Attribution 4.0 International License (http://creativecommons.org/licenses/by/4.0/), which permits use, sharing, adaptation, distribution and reproduction in any medium or format, as long as you give appropriate credit to the original author(s) and the source, provide a link to the Creative Commons licence and indicate if changes were made.

The images or other third party material in this chapter are included in the chapter's Creative Commons licence, unless indicated otherwise in a credit line to the material. If material is not included in the chapter's Creative Commons licence and your intended use is not permitted by statutory regulation or exceeds the permitted use, you will need to obtain permission directly from the copyright holder. 